\title{
Lübnan'da Siyasal Kurumların Yeniden İnşası: Çoğunluk Sisteminden Nispi Temsile
}

\author{
Tahsin YAMAK*, Tuba YILDIZ**, Emre SAYGIN***
}

ÖZ

$\mathrm{Bu}$ çalışmanın amacı, Ortadoğu'nun istikrarsız fakat bölgesini etkileme potansiyeli bakımından önemli ülkelerinden Lübnan'da, toplumsal birlikteliğin ve politik istikrarın teminine yönelik olarak gerçekleştirilen seçim sistemi değişikliğinin, din/etnik grup temelinde kurgulanan devlet yönetiminde ortaya çıkaracağı muhtemel sonuçlar ile sistem değişikliği akabinde gerçekleştirilen seçimlerde parlamentonun 1/3'nü elde eden ittifak cephesinin önemli aktörlerinden Hizbullah'ın siyasal dönüşümünün gerek Lübnan siyaseti ile toplumsal hayatındaki gerekse de Ortadoğu'daki olası etkilerinin Yeni Kurumsal İktisat çerçevesinde analiz edilmesidir. Siyasi görevlerin etnik ve dini gruplar arasında orantılı bir şekilde paylaştırılması esasına göre oluşturulan, buna rağmen temsil sorunlarına yol açan seçim sisteminin daha adaletli bir yapıya dönüştürülmesi yönündeki çabaların, ülkenin siyasal kurumlarının dönüşmesi için önemli bir aşama olduğu; ancak Lübnan siyasetini belirleme noktasında etkin olan İran ve Arap devletleri arasındaki yıkıcı rekabetin Hizbullah'ın yükselen konumu nedeniyle İran lehine değişmesinin, ülkede idari, politik ve sosyo-ekonomik yapının reforme edilmesi suretiyle, kurumsal dönüşümün sağlanması yönündeki en önemli engellerden birisi olduğu sonucuna ulaşılmıştır.

\author{
Anahtar Kelimeler: Lübnan, Seçim Sistemleri, Çoğunluk Sistemi, Nispi Temsil, Kurumsal Değişim
}

JEL Sinıflandırması: D71, D72, H11

\section{Restructuring of Political Institutions in Lebanon: From Majoritarian to Proportional Representation}

\begin{abstract}
In Lebanon, one of the important countries in the Middle East region, which is unstable, but important in terms of its potential to affect the region, changes have been made in the electoral system to ensure social unity and maintain political stability. In this study, the effects of the electoral system change, on the possible results for government administration based on religion/ethnic group and the possible effects of Hezbollah's political transformation in Lebanese politics and the Middle East region were analyzed by using Institutional Economics thoughts. According to this, created on the basis of proportional allocation of political tasks between ethnic and religious elements, but try to have the electoral system leading to representation problems become fairer is an important step for the change of the country's political institutions. But the fact that the destructive competition between Iran and Arab states, which are active at determining Lebanese politics, has changed in favor of Iran due to the rising position of Hezbollah, is the biggest obstacle to institutional change in the country by reforming the administrative, political and socio-economic structure.
\end{abstract}

Keywords: Lebanon, Electoral Systems, Majority Systems, Proportional Representation, Institutional Change

JEL Classification: D71, D72, H11

Geliş Tarihi / Received: 13.03.2020 Kabul Tarihi / Accepted: 07.04.2020

\footnotetext{
* Dr., Bayrampaşa Belediyesi İç Denetçi, tahsinyamak@ gmail.com, ORCID: 0000-0001-8831-7448.

** Araş. Gör. Dr., Trakya Üniversitesi, İlahiyat Fakültesi, İslam Tarihi ve Sanatları Bölümü, tubayildiz@trakya.edu.tr, ORCID: 0000-0002-7152-4421.

*** Dr., Beykoz Belediyesi Teftiş Kurulu Müdürü, sayginemre@gmail.com, ORCID: 0000-0003-2939-1562.
} 


\section{GİRİŞ}

Ortadoğu, muhtemelen en çok yapay sınırlara ve sorunlu yönetimlere sahip ülkelerden müteşekkil bölgedir. Kolonyal yönetim modellerinin terk edilmeye ve ülkelerin bağımsızlıklarını kazanmaya başladıkları Dünya Savaşları ertesinde, bölgede mevcudiyetini sürdürmekte olan sömürge yönetimleri, bu modeli terk etmeye, suni bir tasnif etrafinda ve her toplumun kendi tarihi birikiminden de referans alacak şekilde yeniden teşkilatlandırma noktasında bir tutum sergilemişlerdir. Bölgede yer alan ülkeler, girift ilişkiler barındıran sosyolojik, siyasal ve ekonomik etkenler bağlamında, genellikle otoriter özellikler arz eden monarşi yönetimleri şeklinde kurgulanmışlarsa da kısmen hibrit rejim uygulamalarına yer verilmiş, bazı ülkelerde ise, demokratik sisteme yakın hususiyetler arz eden yönetimlerin oluşmasına dikkat edilmiştir.

Çalışma kapsamında siyasal değişimin analize konu edileceği Lübnan, etnik, dini ve kültürel toplulukların geniş kapsamlı ve kısmen demokratik bir ortak yönetim modeli çerçevesinde örgütlendiği kendine has siyasal kurallar perspektifinde "ortaklaşmact" parlamenter bir cumhuriyet modeli ile yönetilmektedir. Bu modele göre, Cumhurbaşkanlığı Marunî Hristiyanların, Başbakanlık Sünnilerin, Meclis Başkanlığı ise Şiilerin elinde bulunmaktadır. Diğer azınlıklar ise farklı düzeylerde çeşitli devlet görevleri almak suretiyle devlet yönetiminde söz sahibi olmaktadırlar. Bahse konu sistem ve devlet yapısı ise esasen 1932 yılındaki ilk ve tek nüfus sayımına göre şekillenmiş olup, dinsel ve mezhepsel demografi ile oldukça ilişkilidir.

Ülkede uzun zamandır siyasi görevlerin etnik ve dini unsurlar arasında orantılı bir şekilde paylaştırılması esasına göre oluşturulan bu sistemin temelini oluşturan seçimlerin gerçekleştirilmesinde, bir seçim çevresinde en çok oyu alan siyasi partinin o çevredeki temsilin tamamına sahip olmasına imkân veren çoğunluk sistemi uygulanmaktaydı. Filistinlilerin Lübnan'da artan etkinlikleriyle birlikte nüfus dengesinin Sünniler lehine değişmesi akabinde başlayan iç savaş, 1979 yılında gerçekleşen İran Devrimi ertesi İran'ın "Devrim İhract" politikası çerçevesinde Lübnan Şiileri ile gerçekleştirdiği yoğun ilişkiler sonucunda Hizbullah Örgütünün ortaya çıkması ile hızla güçlenmesi gibi temel hususlar, zaten son derece kritik dengeler üzerine kurulu yönetim yapısının ve buna bağlı olarak seçim sisteminin sorgulanmasına sebebiyet vermiştir.

İç savaşın ertesinde imzalanan Taif Antlaşması ile Lübnan'ın siyasal sistemi önemli değişikliklere uğramış ve Sünnilerin nüfus artışı ve etkinlikleri göz önünde bulundurularak, Marunî cumhurbaşkanının bazı yetkileri Sünni başbakana devredilmiş, parlamentodaki Hıristiyan-Müslüman temsilcilerin sayısı eşitlenmiş ve Hizbullah'ın ayrıcalıklı bir konum elde etmesi sağlanmıştır. Bu noktada, Lübnan siyasetinde özellikle Suriye Baas rejiminin ağırlığı güçlenmiş ancak Şubat 2005 tarihinde Refik Hariri bombalı bir suikast saldırısı sonucu hayatını kaybetmesi sonucu "Sedir Devrimi" olarak isimlendirilen gelişmelerin ardından Suriye tüm askerî ve istihbarat personelini ülkeden çekmek zorunda kalmış, ülkedeki Suriye karşıtları ve yanlıları arasındaki ayrışma daha da derinleşmiştir.

2006 yılı Temmuz ayında Hizbullah'ın İsrail'e saldırı başlatması, görev süresi biten Cumhurbaşkanı yerine seçilecek yeni devlet başkanının seçimi için meclis oturumlarına katılmaması ve seçimlerin tekrarlanmasını istemesi hususları Lübnan siyasal sistemin kilitlenmesine sebebiyet vermiş ve büyük çatışmaların fitilini ateşlemiş̧ir. 2009 seçimlerini Saad Hariri öncülüğündeki ittifak kazandıysa da Hizbullah'ın parlamentodan çekilmesi nedeniyle siyasal sistem yine işlevsiz kalmıştır. Arap İsyanları dolayısıyla yaşanan kitlesel göçler ile DAEŞ tehlikesinin ülkede boy göstermesi, kırılgan Lübnan siyasetini daha da istikrarsız bir hale getirmiş, bütün bu siyasal krizler ise Hizbullah'ın ülke siyasetindeki gücünü tahkim etmesine imkân vermiştir. 
Lübnan siyasetine dair en önemli gelişmeler 2014 y1lı içerisinde gerçekleşmiş ve Devlet Başkanının belirlenememesi hususu parlamento seçimlerini etkilemiş, uzlaşma sağlanamaması sebebiyle meclisin görev süresi 2017 yılına uzatılmıştır. Bu süreçte, Lübnan meclisi, Cumhurbaşkanlığ seçimi için tam 45 başarısız girişimde bulunmuş ve nihayet iki buçuk yıllık krizden sonra 31 Ekim'de 2016'de Mişel Avn Cumhurbaşkanı seçilmiştir. 6 Mayıs'ta 2018 yapılan genel seçimlerin ardından Hariri öncülügünde yeni hükümet, 9 ay süren çalışmaların ardından 31 Ocak tarihinde kurulabilmiştir. Ancak bu hükümet de uzun süreli olmamış, ülkede başlayan protestolar nedeniyle 29 Ekim'de istifa etmiş ve yerine 21 Ocak 2020 tarihinde, daha çok Hizbullah ve Şii grupların destek verdiği Hassan Diyab Başbakanlığında yeni bir hükümet kurulmuştur.

Geçen süreçte yaşanan tüm bu hususların yanı sıra toplumsal grupların/aktörlerin siyasal sisteme katılım talepleri artmış ancak siyasal sistem siyasal, sosyal ve ekonomik sorunların çözümünü üreten bir mekanizma olmaktan ziyade bizatihi krizin/sorunun merkezi halini almıştır. $\mathrm{Bu}$ noktada, seçim sisteminde uygulanmakta olan çoğunluk sistemi ise yönetimdeki istikrarsılılı̆̆ perçinleyen önemli bir sorun olarak ön plana çıkmıştır.

Bu çalışmanın amacı Lübnan'da, toplumsal birlikteliğin ve politik istikrarın teminine yönelik olarak çoğunluk siteminden nispi temsile geçişi öngören seçim sistemi değişikliği ve bu sürecin akabinde ülke siyasetinde yer alan çeşitli toplumsal grupların farklılaşan siyasal ağırlıkları ve temsiliyet durumlarının ülkenin genel siyasi istikrarına ve geleceğine dair etkilerinin Yeni Kurumsal Iktisatın teorik izahatlarından faydanılmak suretiyle analiz edilmesidir. Lübnan'da siyasal istikrarın ve kurumsal dönüşümün teminine yönelik çabaların ortaya konulmasının da planlandığı bu çalışma, seçim sistemlerine ilişkin detayların bulunduğu birinci bölüm, Lübnan siyasetinde temsiliyet sorunlarının tarihi kökenlerinin tartışıldığı ikinci bölüm ve ülkede siyasal kurumlarının gelişiminin analiz edildiği üçüncü bölümden meydana gelmektedir.

\section{SEÇIM SISTEMLERİ: ÇOĞUNLUK SISTTEMİ \& NISPII TEMSIL}

Demokrasi kavramı, çoğu kez halkın kendi kendini yönetmesi olarak tanımlanmaktaysa da liberal sistem uygulamaları bağlamında, yöneticilerin yönetilenler tarafından serbest/özgür ve adil seçimler vasıtasıyla seçildiği, hak ve özgürlüklerin koruma altına alındığı, bireyin sosyal faydasının öncüllendiği ve hukukun üstünlüğünün temel alındığı, temsili bir yönetim modeline evrilmiş bulunmaktadır. Halkın egemenliğini temsil eden demokratik sistemlerin temel koşulu olarak da seçim olgusu ön plana çıkmıştır (Bulut, 2010: 13; Akboğa ve Şahin, 2018: 7-11).

Hâlihazırda devlet ve toplum ilişkilerini sağlayan en önemli araç konumunda olan seçimler, kamu görevini yürütecek kişi ve/veya kişilerin, ilgili seçmenlerce, katılım gösteren adaylar arasında yapılacak tercihlerle tespit edilmesi, diğer bir ifade ile yönetim erkinin devredileceği grubun belirlenerek, yetkilendirilmesi olarak kavramsallaştırılabilir (Türk, 2006: 76; Yüzbaşıŏlu, 1996:105).

Seçimler, yönetim hakkının devrine ilişkin meşruiyeti sağlamakta, seçim sistemleri ise yetkiyi alacak olan seçilenlerin hangi usuller ile belirleneceğinin teknik alt yapısını oluşturmaktadır. Seçim sistemleri, bireysel tercihlerin kolektif tercihler şeklini alması diğer bir ifade ile karar alma yetkisinin temsilcilere devredilmesini ifade eden siyasi temsil kavramının gerçekleşmesini sağlayan temel mekanizmalar olarak ön plana çıkmaktadır. Dar anlamda seçim sistemleri, seçmenlerin oy vererek parti ve/veya aday tercihlerini ortaya koymaları ile bu oyların dağıtılması ve yetki tevdii edilenlerin belirlenmesini ifade etmekteyse de geniş anlamda, seçme ve seçilme hakkı ile seçimlerin organizasyonu gibi seçim sürecine giren ve seçimleri etkileyen birçok farklı unsuru da içermektedir (Nohlen, 1996: 19; Akıncı, 2017: 405; Bulut, 2010: 1). 
Parlamentonun dağılımını, ülkeyi hangi siyasi partinin yöneteceğini, yasaların ve anayasanın kimin tarafından yapılacağını/değiştirileceğini belirleyen ve demokrasinin temel unsurlarıyla illiyet arz eden seçim sistemleri, partilerin yapısını şekillendirmekle birlikte politikacıların davranışlarını ve seçmenlerin oy verme tercihlerini de etkilemekte olan seçim sistemleri bu haliyle önemli siyasi sonuçların meydana gelmesine neden olmakta, ülkenin geleceğinin şekillenmesi noktasında önemli bir konum arz etmektedir (Mainwaring, 1990: 3; Y1ldiz, 2018: 116).

Esasen ideal bir seçim sisteminden bahsetmek pek mümkün gözükmemektedir. Zira ülkelerin, sosyal sınıfların ve bireylerin kendi kişisel deneyimleri doğrultusunda şekillenen demokrasiye dair tutumlarına ilişkin farklılaşmalar, demokrasinin bazı bileşenlerinin diğerlerine göre daha öncelikli haline gelmesine neden olmakta, bu durum ise seçim sistemlerinin ülkeden ülkeye farklılaşmasına sebebiyet vermektedir. Ancak temel olarak ele alındığında, ideal bir sistemin, ülkenin tüm farklılıklarının temsiline zemin hazırlayan adaletli seçimlerin yapılmasına ve istikrarlı bir yönetimin kurulmasına imkân veren bir uyumlaştırma içerisinde olması gerektiği aşikârdır. Ancak bahse konu iki ana ilke diğer taraftan bir tezatı da ifade etmektedir. Zira toplumsal tecrübeler, çoğu kez istikrarı sağlamaya matuf düzenlemelerin temsilde adaletten sapmaya; adaleti temine yönelik düzenlemelerin ise istikrarlı yönetimden kaymalara neden olduğunu ortaya koymaktadır (Yüzbaşığlu, 1996:105; Akboğa ve Şahin, 2018: 9).

Çoğunlukla bağdaşması mümkün olmayan bu iki ana ilkeden taviz verilmek suretiyle bir yol bulunması gerektiği ortadadır. Bu durum ise teknik bir hesaptan ziyade daha çok toplumların demokrasiye dair tutumlarına göre şekillenecek siyasal bir tercih olmaktadır. Zira bilinmektedir ki, aynı oy oranlarına iki farklı formül uygulamak, her parti için seçilen üyeler açısından oldukça farklı sonuçlar doğurabilmektedir. Çatışma kültürünün yoğun olduğu ülkelerde, yanlış kurgulanan seçim sisteminden kaynaklanan nedenlerle yüksek temsil imkânı elden eden ve bu avantajlı konumlarını sürdüren sosyal sınıfların, uzlaşmaya yanaşmayan ya da gerek duymayan tutumları, kendilerine temsil imkânı bulamayan toplumun diğer kesimlerinin dışlandığı, sosyal parçalanmışlığın derinleştiği ve istikrarsızlığın çoğaldığı müşahede edilmektedir (Blais ve Massicotte, 1996: 40; Akyıldız, 2016: 145).

Tüm bu sorunlar çerçevesinde en ideal seçim sistemi ve formülünün ne olduğuna cevap arayan ülkelerin, seçileceklerin sayısı bakımından (tek isimli, listeli), seçim sayısı bakımından (tek turlu, iki turlu) ve seçilenlerin partilere dağılımının hesabı bakımından (çoğunluk, nispi) olmak üzere bu üç temel ayrımın çeşitli kombinasyonlarını kullanmak suretiyle çok sayıda seçim sistemini denedikleri ve toplumsal yapılarına en uygun sistemi bulma yönünde irade gösterdikleri müşahede edilmektedir (Aky1ldız, 2016: 131-132).

Dünya genelindeki örnekler ele alındığında, toplumların oyların parlamentoda temsil edilecek vekil sayısına dönüştürülmesi yöntemleri bakımından iki temel seçim sistemi üzerinde ittifak ettikleri görülmektedir. Bunlar, çoğunluğun temsilinin devletin iyi idaresini sağladığı anlayışına dayanan çoğunluk sistemi ile seçim usulünün öncelikle adalet duygusunu gerçekleştirdiği anlayışına dayanan nispi (orantıll) temsil sistemi olmak üzere iki ana başlık altında tasnif edilmektedir. Ancak yarı nispi (orant1l1) sistemler ve karma sistemler olarak adlandırılan yöntemlerin bulunduğunu da belirtmek gerekmektedir (Yüzbaşığlu, 1996: 106; Norris, 1997: 298; Aky1ldız, 2016: 131; Nohlen, 1996: 21-22; Y1ldız, 2018: 119 ).

Çoğunluk sistemlerinde, oyların çoğunluğunu alan aday/partiler o seçim bölgesindeki seçimi kazanmakta; daha az oy alan aday/partiler ise o bölgede yapılan seçimi kaybetmektedir. Tek-turlu basit çoğunluk, iki-turlu basit veya mutlak çoğunluk ya da alternatif oy gibi farklı türleri bulunan bu seçim sistemi; siyasi partilerin tamamının mecliste temsil edilememesi, vatandaşın oyunun boşa gideceği kaygısıyla oy kullanması suretiyle gerçek iradesini sandığa yansıtamaması gibi handikapları içermesi nedeniyle kutuplaşmalara sebebiyet verebileceği yönünden tenkitlere konu olmaktadır (Nohlen, 1996: 32-33; Yıldız, 2018: 124). 
Nispi (orantıll) temsil ise partilerin meclisteki temsili, aldıkları oy oranlarıyla ve benimsenen seçim formülü türüne bağlı olarak az ya da çok olmak üzere, doğru orantılı olarak belirlendiği seçim sistemi olarak ön plana çıkmaktadır. Nispi temsil sistemleri, en yüksek ortalama/bölen (d'Hondt ve değiştirilmiş Sainte-Lague sistemleri ) ve en büyük bakiye veya kota sistemleri olarak iki alt tipe ayrılmaktadır. Diğer yandan bu sistem, milletvekillerinin seçim çevresinden ziyade daha geniş bir çerçevede dağıtılmasına imkân verip vermemesi bakımından da tek ya da iki kademeleri nispi temsil sistemleri olarak da tasnife tabi tutulmaktadır. Bununla birlikte, nispi temsilin bir türü olarak kabul edilen bir diğer seçim sistemi ise bireysel (dolayısıyla farklı partilerden) adaylara oy verebilmenin avantajlarıla NT'nin orantılı sonuçlarını birleştirmesine imkân veren "devredilebilir tek oy" (single transferable vote, STV) sistemidir. Kullanılan yöntemler nedeniyle ülke genelinde alınan oyların, meclise yansıması bakımından, çoğunluk sistemlerine nazaran daha adaletli bir sonuca yol açtı̆̆ değerlendirilen nispi temsil sistemlerinde, zaruri olan liste uygulamasının, bahse konu listenin içeriğinin belirlenmesinde seçmenin bir etkisinin bulunmaması ve bu durumda seçmenin parti tarafindan belirlenen kişilere oy vermek zaruretiyle karşı karşıya kalması dolayısıyla demokratik temsil yönüyle bazı sorunlar ihtiva ettiği yönünden tenkite konu olmaktadır (Gallagher, 1991: 34-36; Yüzbaşıoğlu, 1996:111-112; Özbudun, 1995: 521-525; Yıldız, 2018: 119).

Esasen herhangi bir seçim sistemini diğerlerinden daha iyi olarak nitelemek pek kolay gözükmemektedir. Örneğin, köklü dini veya etnik bölünmelerin bulunduğu toplumlar için nispi sistem daha kapsayıc olabilmekte ancak bu durum bölünmeleri düzeltmek yerine derinleştirebilmektedir. Esasen seçim kurumlarının belirlenmesi, büyük ölçüde devletlerin demokrasi anlayışı ile paralellik arz etmektedir. Genel olarak bakıldığında, seçim sistemlerinden beklentilerin başında istikrarlı yönetimlerin oluşturulması isteği ön plana çıkmaktadır. Zira siyasal istikrarın güçlü yönetimler eliyle oluşturulacağına dair genel bir kabul bulunmaktadır. Bu noktada, toplumlar da siyasal istikrar arayışlarında, seçim sistemlerine özel bir ehemmiyet arz etmekte, siyasal istikrarsızlıkların çözümü noktasında ise seçim sistemi değişikliklerine başvurdukları görülmektedir. Her ne kadar siyasal istikrarsılılı̆ın aşılması noktasında önem arz ettiği genel kabul görmekteyse de seçim sistemi reformlarının pek kolay gerçekleşmediği, genellikle önemli siyasi kriz ya da yönetim sistemi değişikliği sürecinde gerçekleşebildiği ve az sayıda ülkede siyasal kurumlarda önemli bir dönüşüm olmaksızın değişikliğin yapılabildiği müşahede edilmektedir (Blais ve Massicotte, 1996: 66; Tuncer, 2014: 18; Norris, 1997).

Lübnan'da, "1960 Yasası" olarak bilinen ve çoğunluk sistemini esas alan düzenlemeler gereği partiler veya adaylardan en fazla oyu alan mecliste çoğunluğa sahip olmaktaydı. Bu durum, Lübnan siyasal sisteminde var olan mezhep, din ve etnik kota sebebiyle nüfus ve temsiliyet oranında önemli bir dengesizliğin meydana gelmesine ve zaten yüksek olan siyasi tansiyonun daha da artmasına neden olmaktaydı. Hatta tüm bu siyasi krizler ve ihtilaflar sebebiyle en son 2009 yılında yapılan ve olağan şartlarda beş yılda bir yapılması gereken parlamento seçimleri yaklaşık on y1l boyunca bir türlü gerçekleştirilememişti.

Bahse konu aksaklıkların giderilmesi ve siyasi istikrarın temini bakımından, 17 Haziran 2017 tarihinde büyük tartışmaların neticesinde kabul edilen yeni seçim yasası ile ülke 15 seçim bölgesine ayrılmış ve katılan her partinin aldığg oy oranında milletvekili çıkarabileceği nispi temsil sistemine geçiş yapılmışıı. Ancak "1960 Yasası" olarak bilinen seçim sistemi düzenlemelerinde değişikliğe gidilmesi ve seçime katılan partiler ya da adaylar arasında en çok oyu alanın seçimi kazandığ "çoğunluk sistemi" yerine "nispi temsil" seçim sisteminin getirilmesi tartışmaları, Lübnan'ı yeni bir siyasi krizin eşiğine getirdiği görülmektedir. Şöyle ki, yeni sistemin kabul edilmesinin ardından yapılan ilk parlamento seçimlerinde, birçok kesimin düşmanı konumunda olan ve çeşitli ülkelerin terör örgütü olarak tanımladığı Hizbullah'ın dahil olduğu ittifak cephesinin parlamentonun üçte birini elde etmesi, gerek Lübnan'da gerekse de bölgesinde önemli sonuçların doğmasına sebep olacak bir sürecin başlamasına da sebebiyet vermiştir. 
Çalışmanın ilerleyen bölümlerinde, Hizbullah'ın dahil olduğu ittifak cephesinin parlamento seçimlerinde edindiği başarının yeni seçim sistemi ile ilişkisi, bu durumun ülkenin siyaset kurumunu ve dış politika anlayışını yeniden şekillendirip şekillendirmeyeceği hususları ile bahse konu sürecin Lübnan'ın siyasi kurumları ilekurumsal yap ${ }^{1}$ sınında meydana getireceği muhtemel etkilerin analiz edilmesi amaçlanmaktadır.

\section{LÜBNAN SIYYASETINDE TEMSILIYET SORUNSALI: PARÇALI YAPI \& KIRILGAN DENGE}

Siyasi sisteminde demokrasiyi benimseyen devletlerde temel amaç, temsilcilerini iktidara taşıma yoluyla halkının yönetime katılması ve siyasette karar alma yetkisine sahip olmasını sağlamaktır. Buna göre ulusun egemenliğini temel alarak ülkeyi demokratik sistemle yönetmeyi düşünen bir rejimin, kaynağını halkın temsilcilerinden aldığı bir düzenlemeye sahip olması da kaçınılmaz olmaktadır.

Bugün parlamenter demokrasiye dayalı bir siyasi yapıya sahip olan Lübnan, halkın temsilcileri olan siyasi parti temsilcilerinin ülke yönetiminde yer almaları ilkesini temel almaktadır. Bununla birlikte ayırıcı bir özellik olarak Lübnan'da 18 resmi mezhep grubunun yer alması ve siyasal hegemonyanın bu dini gruplar üzerinden yürütülmesi, parlamentonun yönetimdeki işlevinin de sorgulanmasını beraberinde getirmiştir. Her ne kadar 1991 iç savaşından sonra imzalanan Taif Anlaşmasıyla Lübnan'da mezhepler arasında siyasi bir denge kurma hedeflendiyse de ülkedeki iç dinamikler ve küresel aktörlerin bölge üzerindeki politikaları nedeniyle bu hedefe ulaşılamamıştır. Çalışmanın bu kısmında Lübnan'ın mezhep temelli politik yapısının kökenlerine değinilecek, geçmişten gelen bu kırılgan yapının günümüz siyasi algısı üzerindeki etkileri tartışılacaktır.

\subsection{Lübnan Siyasetinde Parçalı Temsiliyetin Tarihi Kökleri}

Lübnan'a dair yapılan analizlerdeki genel kanı, mevcut siyasi yapının ülkenin 19201943 yılları arasında süren Fransız manda yönetimi sırasında oluşturulduğuna yönelik olsa da politik dengelerin mezhep zemininde kuruluşunun tarihinin çok daha eskiye uzandığı açıktır. Bu anlamda Lübnan sosyo-dini kökleri açısından Sünni ve Şii mezheplerin yanı sıra Katolik, Ortodoks, Protestan ve Yahudi cemaatlerine ev sahipliği yapmış, bu topluluklar bölgenin ekonomik, siyasi ve kültürel koşulları bağlamında gelişerek otorite elde etmeye başlamışlardır. Mezhep gruplarını temsil eden aktörlerin politik arenada yer almalarıyla da zamanla bölgede mezhep siyaseti yerleşmiş, bu açıdan Lübnan, XVI. yüzyıldan XIX. yüzyılın ortalarına kadar iktidar mücadelesinde kazanan tarafa göre dönemsel olarak Sünni, Dürzî ve Marunî mezhebinden olan Emirler ile Emirlerin müsteşarları görevinde bulunan ileri gelen ailelerin ayan- yönetimi altında idare edilmiştir. Bununla birlikte XIX. yüzyılın ortalarına kadar Lübnan'da mezhepler arası krizlere rastlanmamış, çatışmalar daha çok aynı mezhebe mensup yönetici ailelerin iktidar mücadeleleri çerçevesinde ortaya çıkmıştır. 1841 yılında Dürzî ve Marunîler arasında başlayan iç çatışmalar ise mezhepler arası dengelerin sarsılmasına yol açmış, çatışmaların son bulmasıyla oluşturulan yeni idari yapıyla bölge, uzun tarihinde ilk defa mezhep temelli bölünmeye sahne olmuştur.

\footnotetext{
${ }^{1}$ Kurum ve kurumsal yapı kavramları ve buna ilişkin detaylar çalışmanın ilerleyen kısımlarında paylaş1lacak olup, kısaca belirtmek gerekir ise, kurum kavramı, insanlar tarafından oluşturulan ve insanlar arasındaki etkileşimini düzenleyen sınırlamalar ve kurallar bütününü ifade etmektedir. Kurumlar tarafından meydana getirilen kurumsal yapı kavramı ise ekonomik, siyasi ve sosyal faaliyetlerin gelişmesini teşvik edici çeşitli unsurlar olarak tanımlanabilir (North, 2002:9; Demir, 1996: 112, 174, 175).
} 
Ülkenin güneyinin Dürzî Kaymakamlığı, kuzeyinin de Hıristiyan Kaymakamlığı olarak ikiye ayrılmasıyla ortaya çıkan ve "Çift Kaymakamlık Sistemi" adı verilen yeni idari yapıya göre bölgenin geleneksel siyasetini yürüten Emirlik düzeni sona ermiş ve mezhep temsiliyetine dayanan yeni bir proje çizilmiştir. Bu yeni sistem çerçevesinde de ülkenin kuzey bölgeleri Marunî kaymakamın idaresine verilirken, Şam-Beyrut sınırından başlayıp Sayda'ya kadar gelen bölgeler Dürzî kaymakamın yetki alanı içine sokulmuştur. (Ra'd, ty:112) Kaymakamların başkanlığında kurulan meclisler ise Sünni, Şii- Mütevali, Dürzî, Marunî, Rum Ortodoks ve Rum Katolikleri temsil eden birer vekilin temsiliyle işlemeye başlamıştır. Parlamenter sistem tarzında çizilen bu çerçeveyle her mezhep grubunun siyasi iradede söz hakkına sahip olmaları sağlanmış, yeni idari yapı yalnızca tek bir mezhebin siyasi otoritesini ortadan kaldırarak, bir anlamda mevcut siyasi modelin teorik zemininin oluşmasına öncülük etmiştir. (BEO, GG 1013: 1, 18)

Çift Kaymakamlık sisteminin parametreleri Lübnan'ın sosyo-dini yapısını da göz önünde bulundurulmasıyla çizilmiştir ancak bölgedeki kırılgan siyasi yapı da esasen bu dönemde başlamıştır. Karışık mezhep nüfusuna sahip olan köylerdeki seçim ve yönetim sisteminin muğlaklığını koruması, yeteri çoğunluğa sahip olmadıkları için yönetimde söz hakkı alamayan Yahudiler ve Süryaniler gibi mezheplerin haklarının temsiliyeti sorunları, ayrıca siyasi otoriteyi elinde tutan ileri gelen aileler arasındaki iktidar mücadelesinin merkeziyetçi anlayışa karşı olan muhalefetle birleşmesi sistemin ömrünü kısa tutmuş, iki kaymakamın bölüştüğü Lübnan 15 yıl gibi bir süre içinde yeniden çatışmalara sahne olmuştur. Nitekim 1860 Mayısında bu sefer daha büyük çapta çıkan iç savaş, ülkede küresel güçlerin de müdahalesiyle mezhep temelli yeni ama daha kırılgan bir yapının kurulmasına yol açmıştır.

1860 çatışmalarının askeri galibi bir önceki çatışmada olduğu gibi Dürzîler olsa da masa başında kazanan Marunîler olduğu için bölge için kurgulanan siyasal sistem Marunîlerin hâkimiyetinde kuruldu. Bu noktada eşit temsiliyet hakkı ortadan kalkmış, sistem Marunîlerin lehine işlemiş ve yeni kurulan mecliste Marunîler diğer mezheplere oranla daha fazla aza bulundurma yetkisine sahip olmuşlard. Her ne kadar Marunîlerin nüfus yoğunluğu esas alınarak böyle bir oran konulduğu düşünülse de esasen süreç içinde kilise ve Fransa hükümetinin baskın politik gücünün öncü olduğunu söylemekte yarar vardır. Dolayısıyla toplamda 12 azanın temsilcisinin olacağ 1 idare meclisinde 4 vekille Marunîler çoğunluğu elde etmişler, diğer 8 vekil ise Dürzî, Sünni, Şii -Mütevali Rum Ortodoks ve Rum Katolikler arasında bölünmüştür. Ayrıca meclis başkanı olan mutasarrıfın yokluğunda da bir Marunî’nin vekâlet etmesi kabul edilmiş, böylelikle Lübnan'daki siyasi dengenin ağırlı̆̆ 1 Marunîlerin eline geçmiştir. Bu durum esasen yeni sistemde yalnızca Marunîlerin değil, yoğun bir Fransız nüfuzunun da önünü açmış, dünya savaşı sonrasında bölgeye el koyan Fransa, yirmi yıldan fazla sürecek olan manda yönetimini kolaylıkla sürdürebilmiştir.

1914 y1lına kadar işleyen "Cebel-i Lübnan Nizamnamesi" çerçevesinde oluşturulan siyasi sistemin mezhepsel dengeleri oturtması ise kolay olmamıştı. Bir kere mutasarrıflık döneminin ilk yirmi y1lı siyasi, askeri ve hukuki gücün Marunîlerin tekelinde sürdürülmesiyle geçmiş, bu nedenle diğer mezhep temsilcilerinin özellikle de Dürzîlerin yönetime katılma hakları zamanla olabilmişti. Bu durum, Marunîlerin tüm Lübnan'da, Dürzîler, Sünniler, Rumlar ve diğer azınlık grupların ise yalnızca kendi bölgelerinde yönetimin bir parçası olmalarına sebebiyet vermiştir. Küçük alanlarda siyaset yapmaya çalışan bu mezhep grupları arasında yeniden gün yüzüne çıkan rekabet ise Lübnan'da mezhepler arası ittifak çemberinin yeniden genişlemesine yol açmıştı. Örneğin iki önemli Dürzî aile olan Arslanlar ve Canbolatların özellikle mutasarrıflı̆̆ın son on-on beş yılında giriştikleri rekabet ortamı, birbirlerine karşı diğer mezheplerle ittifak yapmalarına sebep olmuş, böylelikle mezhepler arasında kurulan birtakım gruplaşmalar, ülkede kristalize olmaya başlayan siyasi kutuplaşmaların farklı bir yüzünü ortaya çıkarmıştı. Lübnan'ın siyasi tarihinde belirginleşeceği üzere, mezhep birliği arka plana itilmiş ancak bu ittifaklar hiçbir zaman Lübnan'da mezhepler üstü bir yönetim algısını da doğurmamıştı. Nihayetinde de modern Lübnan'ın kuruluşuna giden süreçte, hem geleneksel 
politik zihniyet yerini bir dereceye kadar korumuş, hem de kimlik tanımında mezhepçiliğin Lübnanlılıktan önce geldiği bir durumun ortaya çıkmasına neden olmuştu.

\subsection{Bağımsızlık Sonrası Lübnan'da İdari Yapı ve Siyasi Dengeler}

XIX. yüzyılın en temel vurgusu olan milliyetçilik düşüncesinin Arap dünyasındaki karşılığı, her ülkenin kendi siyasal çıkarları doğrultusunda farklı şekillerde tezahür etti. Bu aşamada milliyetçilik Lübnan'da, Hristiyan kesim için Fransız merkezli bağımsız bir Lübnan iken Müslüman Araplar için ise Suriye'ye bağlı bir Arap İslam Cumhuriyeti şeklinde anlam buldu. Ancak Osmanlı Devleti'nin yıkılışıyla birlikte manda yönetimi altında giren Lübnan için her iki milliyetçilik anlayışı da işlerlik kazanamamış, ülke 1943 yılında bağımsızlığını elde edinceye kadar Fransa'nın mandası altında mezhep temelli yeni bir devletin oluşumuna hazırlanmıştı. Trablus'tan başlayıp Beyrut'u da içine alan ve güneyde Sur şehrine kadar sınırları çizilen yeni Lübnan'ın manda yönetimi altındaki idari yapısı, mezhepsel ilişkilerin siyasi arenadaki karşılığını daha da bölen bir anlama sahip oldu. Her ne kadar mutasarrıflık idaresinde yer alan her mezhebin temsilcisinin olduğu yapı Fransız idaresi altında "Temsilciler Meclisi" olarak evrilmişse de birkaç yıl içinde anayasanın hazırlanması, devlet dairelerinde mezheplerin adil bir şekilde temsil edilmesi ve üst düzey kademelerde yer alacak mezheplerin oranı gibi karmaşık meseleler Lübnan'1 yeniden mezhep krizinin içine sürükledi (Acar, 1989: 26).

1926 'da ülke hala manda idaresi altındayken ilan edilen anayasaya göre mevcut siyasi dağılımdan farklı olarak cumhurbaşkanının Ortodoks, başbakanın Marunî, meclis başkanının ise Sünni olması doğrultusunda alınan karar işlemeye başladı. Meclisin dağılımı ise 5 Marunî, 3 Sünni, 3 Şii, 3 Rum Ortodoks, 1 Rum Katolik, 1 Dürzî ve 1 tane de diğer azınlıkları temsil edecek bir vekili öngörüyordu (Laga, 1991: 79). Mezhep siyasetinin mutasarrıflık döneminden ayrılarak modern siyasete evrilmesinin ilk basamağ 1 olan bu yeni model, ilk olarak Sünni Müslümanlar tarafindan reddedilmiş, daha sonra bu itiraza ülkedeki Şii ve Dürzîler de ortak olmuştu. Bununla birlikte Lübnan tarihi boyunca hiçbir dönem homojen bir mezhep kutuplaşmasına da sahne olmamıştı. Manda idaresi daha çok Marunîleri memnun etmiş, yalnızca ülkedeki Müslümanlar ve Dürziler değil, Rum Ortodoks ve Rum Katolikler gibi Hristiyan gruplar da Marunî ağrılığının hissedildiği bir siyasal sistemden rahatsızlık duymaya başlamışlardı (Zübyan, 1977: 101-102). Bu rahatsızlık modern Lübnan'ın ilk mezhepler arası bloğunu oluşturmuş, kısa ömürlü olsa da 1932 yılında Antoun Saada liderliğinde Dürzî, Müslüman ve Marunî olmayan Hiristiyanlardan oluşan Ulusal Blok kurulmuştu (Acar, 1989: 29).

22 Kasım 1943 yılında gerçekleşecek olan bağımsızlıktan bir yıl önce ise Lübnan'da yapılan meclis seçimlerinde başlayan mezhepsel temsiliyet sorunu yeni Lübnan'daki dengelerin sarsılmasında önemli bir etken oldu. Ülkenin demografik yapısına dayalı bir temsiliyet ön görülmekle birlikte Hristiyanların ülke yönetiminde elde etmek istedikleri siyasi üstünlük ortalama 55 milletvekilinin 35'nin Hristiyan olmasına dair planların yapılmasına yol açıyordu. Haziran 1943'de ilan edilen anayasanın 49'uncu maddesine göre 54 milletvekilinin 18'i Marunî, 6's1 Rum Ortodoks, 3'ü Ermeni Ortodoks, 3'ü Rum Katolik ve ikisi diğer azınlık Hıristiyanlardan seçilecek vekillerden oluşacakken, Sünnilerden 10, Şiilerden 9, Dürzîlerden de 3 vekilin temsilci olması kararlaştırılmıştı (El Vaili ve Naci, 2014:153). Ülkedeki Müslümanlardan gelen muhalefet ise bu noktada zayıf kalacak, bağımsızlıktan sonra devlet kademelerinde diğer mezhep gruplarına daha fazla görev verilse de kilit noktalar yine Hristiyanların idaresine verilecekti. 
Tablo 1: Lübnan Parlamentosundaki Siyasi Partiler ve Temsilcileri (1951-1972)

\begin{tabular}{lccccccc}
\hline & $\mathbf{1 9 5 1}$ & $\mathbf{1 9 5 3}$ & $\mathbf{1 9 5 7}$ & $\mathbf{1 9 6 0}$ & $\mathbf{1 9 6 4}$ & $\mathbf{1 9 6 8}$ & $\mathbf{1 9 7 2}$ \\
\hline Ermeni Taşnak Partisi & 2 & 2 & 3 & 4 & 4 & 3 & 2 \\
İlerici Sosyalist Parti & 3 & $2-4$ & 3 & 6 & 6 & 5 & 4 \\
Ketaib Partisi & 3 & 1 & 1 & 6 & 4 & 9 & 7 \\
Ulusal Blok & 2 & 3 & 4 & 6 & 2 & 5 & 3 \\
Ulusal Liberal Parti & & & & $4-5$ & 6 & 8 & 7 \\
Suriye Sosyal Milliyetçi Partisi & & & 1 & & & & \\
Baas & & & & & & & 1 \\
Nasırcı Halk Örgütü & & & & & & & 1 \\
Kurtarıcılar -Najjadeh- & & & & 1 & & & 3 \\
Demokratik Sosyalist Parti & & & & & & $\mathbf{2 7}$ \\
Toplam & $\mathbf{1 0}$ & $\mathbf{8 - 1 0}$ & $\mathbf{1 2}$ & $\mathbf{2 7 - 2 8}$ & $\mathbf{2 2}$ & $\mathbf{3 0}$ & $\mathbf{2 8}$ \\
\hline
\end{tabular}

Kaynak: http://almashriq.hiof.no/ddc/projects/pspa/krayem/krayem.html

Bağımsızlıkla birlikte Lübnan parlamentosunda mezhep temsiliyeti farklı muhalif grupların politik çıkarları bağlamında hareket etmeleriyle siyasi sistemin kırılganlaşmasına da sebep olmuştu. Bu anlamda Lübnan, 1952'den 1975 iç savaşın başlangıcına kadar geçen sürede Dürzîlerin, Marunîlerin, Şii ve Sünnilerin, ayrıca Ortodoksların birbirlerine karşı oluşturdukları ittifak bloklarının çekişme alanına dönüşürken, Filistin meselesiyle birlikte Sünnilerin ve Filistin sorununun Lübnan'1 ilgilendiren kısmında öncü olan Dürzîlerin mezhepsel yönetim biçimini farklı bir düzlemden değerlendirmelerinin önünü açtı. Her ne kadar İsrail'in Filistin topraklarındaki hâkimiyetiyle birlikte Lübnan'a göç eden Filistinli nüfusun önemli bir bölümü ilk aşamada Lübnan'1 yeni bir savaş alanı olarak görmeyip, ülkenin politik sisteminden kendilerini uzak tutacak ve kendi yurtlarına geri dönebilecekleri bir süreci öngörse de 1960'larla birlikte kurulan Filistin Kurtuluş Örgütü, El Fetih ve diğer siyasi oluşumlar, Filistinlilerin Arap dünyasında ulus ve vatan hakları için savaşma imkânı elde etmelerini sağladı (Ganley, 2012: 19). Lübnan'daki mülteci kamplarında kurulan askeri eğitim merkezlerinin yanı sıra, İsrail'le savaşta Lübnan'ın karargâh olarak kullanılmaya başlaması hem Lübnan'ı kendi iç savaşına doğru yöneltti, hem de büyük çatışmaya doğru farklı siyasal bloklar arasında mezhep temelli olmayan ittifakların kurulmasına yol açtı.

Parlamentodaki siyasi partilerin politik ideolojilerinin zeminini oluşturan mezhepçilik, potansiyel gücünü korumaya devam etse de 1960'larla birlikte ortaya çıkan yeni siyasi gelişmeler, Lübnan'da öne çıkan siyasi partilerin Filistin davasında alacakları rollerini belirlemeleri açısından farklı gelişmeleri içine çekti. Buna göre yukarıdaki tabloda yer alan partilerden Dürzî İlerici Sosyalist Parti lideri Kemal Canbolat'ın liderliğinde Nasırcı Halk Örgütü, Demokratik Sosyalist Parti ve Arap Ulusalcı Hareketinin de içinde bulunduğu Filistin yanlısı karma bir koalisyon oluşurken, bu koalisyonun oluşturduğu demografik ve militer güç bir süre sonra meclisteki mezhepsel temsiliyet oranının da sorgulanmasına yol açtı (Köprülü ve Ebrem, 2013: 13). Diğer taraftan, iç savaş öncesi mecliste şekillenen bu paralel siyaset, yalnızca partilerin değil, devlet kurumlarının da aciz kalmasına ve mezhep ideolojisinin parti temsilciliği niteliğindeki misyonunun yitirilmesine neden oldu.

Filistin meselesinin Lübnan'da iç savaşa evrildiği 1970'ten Taif Anlaşmasının yapıldığı 1990 yılına kadar geçen sürede ise ülke iki siyasi kutba bölündü. Bir tarafta, İlerici Sosyalist Parti Genel Başkanı Kemal Canbolat liderliğindeki solcu ve milliyetçi bir ittifak olan Lübnan Ulusal Hareketi, diğer tarafta Ketaib Partisi liderliğindeki sağcı muhafazakâr bir ittifak olan Lübnan Cephesi vard1. 1982'den sonra, her iki kutuptan birçok siyasi parti, militarizasyon 
sonucunda partilerin askeri kanatları tarafindan kontrol edilen milislere dönüştü. Nihayetinde de siyasi partiler demokratik temsil yetkilerini kaybetti ve temsil ettikleri halk arasında büyük bir uçurum ortaya çıktı (Krayem, ty).

Aynı zamanda 1970'lerde, özellikle demografik etkiler nedeniyle, Hıristiyanlar ve Müslümanlar arasında şimdiye kadar var olan nüfus oranı Müslümanlar lehine değişti. Sonuç olarak da 1932 nüfus sayımına dayanan siyasi gücün dağılımı demografik gerçekleri yansıtmayı bıraktı ve bu gelişmeler Müslümanların kurumsal reform talebini artırdı (Diss ve Steffen, 2017:4). Diğer taraftan seçim kanunu üzerinde sıklıkla yapılan değişimler istikrarsızlığa da neden olmuş, siyasi aktörlerin parlamentodaki ittifakları veya ihtilafları doğrultusunda seçim bölgeleri sürekli bölünerek farklı listeler oluşturulmaya çalışılmıştı. Bu bağlamda 1953-1972 yılları arasında Lübnan 9 seçim bölgesinden 26- 33 arası daha küçük bölgelere ayrılmış, 1992 seçimleri için ise istisnai tutarsız bir bölünme gerçekleşerek ve bazıları nispeten büyük, bazıları nispeten küçük olan 12 farklı bölge oluşturulmuştu. İç savaştan sonra ilan edilen yeni yasayla da idari illerin seçim bölgelerine bir istisna getirilmişti ancak toplumsal bölünme de gerçekleşmiş, bu anlamda da siyasi olduğu kadar mezhepsel hegemonya gün yüzüne çıkmaya başlamıştı (Majed, ty: 44). Dolayısıyla iç savaşa son veren Taif Anlaşması, Cumhurbaşkanının gücünü Başbakan ve Parlamento Başkanı lehine azaltmıştı ancak daha istikrarlı bir yönetim yapısının yeniden oluşturulması sürecini başlatmak için en iyi düzenleme olarak kabul edilememişti.

İç savaş sonrası zuhur etmeye başlayan ve modern Lübnan'ın en önemli politik aktörleri olacak olan Emel Hareketi (1969) ve Hizbullah (1985) ise mecliste hem Hiristiyan hem de Müslüman bloklar arasında yükselerek daha sessiz olan kitlelerin yükselen sesi olmayı başaran iki önemli platformdu. Bu aşamada Şiilerin hem göçlerle nüfus yoğunluğu oluşturmaları hem de gelişen kentleşmeyle birlikte ekonomik sistemde yer almaları, temsilcilerinin siyasette etkin rol oynamalarını sağlamış, bu sayede de 1992 seçimlerinde Emel ve Hizbullah Güney Lübnan'dan ve Bekaa'dan toplam 12 sandalye kazanarak siyasi etkinliklerini artırmaya başlamışlardı.

Tablo 2: Lübnan Parlamentosundaki Siyasi Partiler ve Temsilcileri (1992)

\begin{tabular}{lcr}
\hline Partiler & $\begin{array}{c}\text { Sandalye } \\
\text { Sayısı }\end{array}$ & Mezhebi Temel ve Bölgeler \\
\hline İlerici Sosyalist Parti & 4 & Dürzi-Cebel-i Lübnan (Şuf, Aley) \\
Suriye Sosyal Milliyetçi Partisi & 6 & Grek Ortodoks - Cebel-i Lübnan (Küre ve Beyrut) \\
Baas & 2 & Laik \\
Emel Hareketi & 4 & Şii- Güney Lübnan \\
Hizbullah & 8 & Şii - Güney Lübnan, Bekaa \\
Lübnan Komünist Partisi & & Laik, Ulusal \\
Ketaib Partisi & & Marunî, Cebel-i Lübnan (Kisirvan, Metn ve \\
Beyrut)
\end{tabular}

Kaynak: http://almashriq.hiof.no/ddc/projects/pspa/krayem/krayem.html

Taif anlaşmasıyla birlikte devlet-toplum ilişkilerinin bel kemiği olan mezhep kimliğinin kurumsallaşması daha net bir biçimde ortaya çıkarken, Hizbullah'ın askeri gücü ve ordusu da 
meşruiyet kazanmıştı. Bu noktada, meclisteki milletvekilleriyle Lübnan parlamentosundaki siyasi güç dağılımındaki payını alan Hizbullah, 2005'ten sonra Suriye karşıtı kurulan ve Sünni bloğun başını çektiği 14 Mart hareketine karşı 8 Mart hareketini kurarak siyasi dengelerde Suriye meselesini orta noktaya koymuş oldu. Bununla birlikte, bu kutuplaşma Hizbullah'a seçmen gözünde puan kaybettirecek ve 2009 seçimlerinde 8 Mart koalisyonu 14 Mart karşısında hezimete uğrayacaktı.

\subsection{Mevcut Siyasal Sistemde Temsiliyet Sorunu}

Mayıs 2018'de dokuz yıl aradan sonra genel seçimlerini yapan Lübnan'da yeni bir kırılma döneminin başlayacağına dair ilk işaret Hizbullah ve müttefiklerinin oyların yüzde \%53'ünü alarak meclisteki 128 sandalyenin 67'sine sahip olmaları oldu. Haziran 2017'de ilan edilen yeni seçim yasasına göre seçim bölgelerinin 26 'dan 15 'e düşürülmesi ve yasanın nispi seçim sistemine göre yeniden düzenlenmesiyle ülkede otoriteyi elinde bulunduran siyasi elitlerin yanı sıra küçük siyasi partilere de meclis yolunu açmak hedeflendi ancak Hizbullah tek başına 13 milletvekiline sahip olarak seçimden en güçlü aktör olarak çıtı. Yalnızca güney Lübnan'da değil Beyrut ve kuzey bölgelerden de önemli oranda oy almas1 ise partinin sınırlı güce sahip bir kurum olmaktan çıkıp -çoğu kez tanımlandığı şekliyleşiddet eğilimli devlet dışı aktörden ziyade, ülke siyasetinde etkili ve ağırlığa sahip merkezi bir oluşuma dönüştüğünü gösterdi. Ayrıca partinin yalnızca politik arenada değil Lübnan'ın eğitim, sosyal ve ekonomik sektörlerinde kendi paralel kurumlarını yaratması ve eğitim verilen okullarda Şii gençliğini ideolojik olarak aşılaması, öte yandan sosyal hizmetler ağıyla da vatandaşlara verdiği sağlı ve hayır hizmetleri, toplumsal alandaki yaygın etkisinin seçimler üzerindeki yansımasını gün yüzüne çıkardı. Bu anlamda 2009 seçimlerinde oyların \%5'ini alan Hizbullah, son seçimde oy oranını \%15'e çıkararak toplumsal güvenini artırdığını da gösterdi. Öte yandan Saad Hariri’nin Müstakbel partisinin oylarının üçte birini kaybettiği seçim, yalnızca demografik değişimin bir sonucu olarak değil, Hizbullah'ın militer gücünün halk üzerinde oluşturduğu etkinin bir yansıması olarak yorumland1 (Yetim, 2015: 61; Counter Extremism Project, 2018).

Bununla birlikte seçimlerde Cumhurbaşkanı Mişel Avn'ın partisi olan Özgür Yurtsever Hareketi'nin mecliste 29 koltuk elde etmesi, Samir Caaca'nın partisi Lübnan Kuvvetleri'nin de koltuk sayısını 8'den $15^{\prime}$ 'e çıkarmas1 Hristiyanların temsiliyetini güçlendirirken Hizbullah'ın oynayacağı rolün dengelenmesi açısından dikkat çekmekteydi. Son olarak özellikle 2015 yılında Lübnan'daki çöp krizi ve Suriye savaşına Hizbullah yoluyla dâhil olma nedeniyle oluşan protestolardan doğan bazı sivil toplum kuruluşlarının seçimlerde bağımsız adaylar olarak katılmaları, ancak yalnızca bir koltuk edinebilmeleri de bir hayal kırıklığı oluştururken, siyasi temsiliyetin uzun bir süre daha politik elitlerin tekelinde kalmasina neden oldu.

Seçim tartışmalarının genellikle siyasi çerçeveden uzak kalmasıyla birlikte 2005 y1lıyla birlikte görünür olan iki baskın kutup olan 14 Mart ittifak1 (Hariri ve müttefiklerinden oluşan Suriye karşıtı bir rejim koalisyonu) ve 8 Mart (Hizbullah ve müttefiklerini içeren koalisyon) arasındaki rekabet ve bölünmenin Mayıs 2018 seçimlerinde zayıfladığı ise tüm siyasi partiler arasındaki karmaşık ittifaklarla kanıtlanmıştı. Bir diğer ifadeyle bir önceki seçimlerde müttefik olan partilerin, 2018'de bazı bölgelerde ittifaklarını korurken bazı bölgelerde birbirlerine karşı yarıştıkları görüldü. Örneğin Müstakbel partisi ve müttefiki olan Lübnan Kuvvetleri, Cebel-i Lübnan (Şuf-Aley), Bekaa (Baalbek-Hermel) ve Kuzey (Akkar) bölgelerinde birleşik listelere sahipti ancak adayları, Hariri'nin eski siyasi rakibi olan Özgür Yurtsever partisi ile ittifak kurduğu Betrun, Küre, Zagharta ve Bişarri gibi Kuzey Lübnan ile Bekaa (Zahle)'da rakip listelerde yer almışlardı. Paralel biçimde Özgür Yurtsever Partisi'nin Hariri'nin seçim bölgesi olan Beyrut'ta Hizbullah ve 
Emel ile ittifak yapmıştı ancak Sayda ve Cezzin gibi güney bölgeleri ile Cebel-i Lübnan'da onlara karşı yarışmıştı (Moussa, 2018: 6). Bu karmaşık durumun yarattığı kısmi kargaşa ise seçimlere katılımın 2009 seçimlerine oranla düşmesini ve bazı seçmenlerin seçimlere karşı ilgisizliğini de açıklamaktaydı.

6 May1s seçimlerinin ardından uzun bir hükümet kurma sürecini başlatan Lübnan'da güç dengesinin dağılımı beklenenler kadar kolay olmadı. En geç Ağustos sonu kurulması planlanan yeni hükümet için bir araya gelen siyasi liderlerin kabinede daha fazla bakanlık elde etme çabaları hükümet kurma sürecini kesintiye uğratırken görüşmeler kısa süre sonra tıkanmaya başladı. Siyasi kırılganlığın en görünür olduğu nokta ise sağlık, eğitim ve mülteci bakanlıkları gibi kilit noktalarda partilerin kendi temsilcilerini görmek istemeleri yönünde oldu. $\mathrm{Bu}$ noktada Hizbullah, istediği bakanlıkları büyük oranda elde ederek parlamentodaki başarısını bakanlıklar düzeyinde de göstermiş oldu.

31 Ocak 2019'da hassas dengeler üzerine kurulan Ulusal Birlik Hükümeti'nin bir yılını doldurmadan düşmesi ise 17 Ekim 2019'da başlayan protestoların ülke çapında yayılması ve gerek ulusal gerekse de küresel düzlemde geniş yankı bulması nedeniyle gerçekleşti. Lübnan'da yeni bir hükümet krizinin oluşmasına yol açan protestocular sivil devlet taleplerini dile getirerek Taif anlaşmasına son verilmesi ve siyasi temsiliyetin seküler temeller üzerine oturması yönünde baskı kurdular. Ancak ülkenin iki yüz yıldan fazla bir süredir dayandığı mezhebi zeminin oluşturduğu siyasal sistem bu talepleri görmezden gelerek teknokrat hükümet modeli üzerine yoğunlaşmaya başladı. 21 Ocak'ta Hasan Diyab'ın başbakanlığında kurulan teknokrat hükümette İlerici Sosyalist Parti, Müstakbel Partisi, Lübnan Kuvvetleri Partisi ve Ketaib Partisi yer almazken, yeni hükümet göstericiler tarafından kabul görmedi. Yeni kabinenin çoğunlukla akademisyenler ve eski bakanlık danışmanlarını kapsayan yeni yüzlerden oluşuyor olması, üstelik ülke tarihinde ilk defa savunma bakanlığ 1 gibi önemli bakanlıklara bayan siyasetçilerin getirilmesi farklı bir somut adım olarak görüldü ancak müzakereler sırasında geleneksel siyasi gruplar arasındaki pazarlıklardan doğan güvensiz ortamın birçok Lübnanlı için çok tanıdık olması, gösterilerin sona ermesindeki engellerden biri oldu. $\mathrm{Bu}$ nedenle de mevcut hükümetin işlevsiz olacağı kanısında olan Lübnan halkı teknokrat bir oluşuma karşı çıkarak öncelikle anayasal sistemin değişmesini ve yeni kurulacak hükümetin sivil bir siyasi anlayışa sahip olmasını talep etmektedir. Bu anlamda Lübnan'ın uzun vadedeki siyasi geleceğinin parti politikalarından öte yeni bir kurumsal siyasete evrilmesi gerekliliği ön plana çıkmakta, bu kurumsallaşmanın da mezhepler arası dengeyi korumaktan ziyade mezhepler üstü bir zemine oturtulması istikrarın sürdürülebilirliği açısından önem arz etmektedir.

\section{LÜBNAN'DA SIYYSAL KURUMLARIN GELIŞ̧IMI: NITEL ÖZELLIKKLERIN NICEL ANALIZI}

Yirminci yüzyılın başlarında ana akım iktisat teorisine karşı tepkiler ve reform önerileri ekseninde ortaya çıkan, analize işlem maliyetleri, mülkiyet hakları, eksik sözleşmeler, yatırımcının korunması, politik haklar ve sivil özgürlükler, siyasal istikrar ve yolsuzluğun önlenmesi ile ifade özgürlüğü gibi kurumsal açıklayıcılar katarak, ana akım iktisadın reformist bir tamamlayıcısı olarak ön plana çıkan Yeni Kurumsal İktisat (YKİ), ülkelerin iktisadi/sosyal/siyasal gelişmelerinin anlaşılması ve açıklanması ile devlet ve toplum ilişkilerinin anlamlandırılması noktasında önemli bir teorik perspektif olarak ön plana çıkmış ve popüler olmuştur.

İnsanlar tarafından oluşturulan ve aralarındaki ilişkileri şekillendiren/kısıtlayan genel kabul görmüş alı̧̧kanlık biçimleri olan ve bir ekonomide teşvik yapılarını ortaya çıkaran hususlar ile bir toplumda oynanan oyunun kuralları olarak tanımlanabilecek "kurum"lar, geçmişten günümüze süregelen düşünce ve davranışlarını şekillendiren yazılı/yazısız kurallar 
bütünü olarak aktörler arası ilişkileri net kurallara indirgemektedir. Yeni Kurumsal İktisada göre, alışkanlık, düşünce ve gelenekler bireyin davranışlarını, bu davranışlar ise "kurumsal yapı"yı şekillendirmektedir. Bu kurumsal çerçevenin sunduğu firsatlardan yararlanmak için ortaya çıkan "kuruluş"lar ile ekonomik yapının desteklediği bilgi ve yetenek türleri ise kurumsal yapının zamanla değişmesine neden olmaktadır. Ekonomik aktörler arası ilişkileri tanzim/yönlendirme hususunda son derece kritik bir rolü bulunan işbu kurumların değişmesi ise siyasal, sosyal ve ekonomik kalkınmayı meydana getiren en önemli unsurlardan birisine karşılık gelmektedir. $\mathrm{Bu}$ noktada, her toplum için farklı olan bu değişim ve gelişim süreçleri olacağ 1 ve bunun da farklı kültür birikimlerinin oluşmasına sebebiyet vereceği gerçeği perspektifinde, toplumların siyasal, sosyal ve ekonomik sorunlarına farklı politika önlemleri ile çözüm sunmanın önemi ve gereği ortaya çıkmaktadır (Çetin, 2012: 44; Orhan, 2011: 60; North, 2002:9).

Yeni Kurumsal İktisat, Ortadoğu bölgesinin en istikrarsız fakat bölgesini etkileme potansiyeli bakımından önemli ülkelerinden Lübnan'da, toplumsal birlikteliğin ve politik istikrarın teminine yönelik olarak gerçekleştirilen seçim sistemi değişikliğinin, din/etnik grup temelinde kurgulanan Cumhuriyet rejiminde ve devlet yönetiminde ortaya çıkaracağı/çıkardığı muhtemel sonuçların anlaşılması/anlamlandırılması ile bundan ortaya çıkması muhtemelen sorunların bertarafına yönelik izahatlarda bulunulabilmesine imkân sağlamaktadır. Bu noktada kurum kavramının hangi şekilde tasnif edildiğinin izah edildiğinin ortaya konulması ile çalışmanın temel parametresi konumunda olan "siyasal kurum"ların teorik olarak izah edilmesi önem arz etmektedir. Genel olarak "kurum"lar, mülkiyet haklarının güvence altına alındığı, yolsuzluk ve suiistimalin kontrol edildiği, sözleşmelerin uygulanabilmesine ilişkin mekanizmaların oluşturulduğu ideal şartlara haiz olması çerçevesinde "kapsayıcı", aksi kurumlar ise "dışlayıcı" olarak adlandırmaktadırlar. Yine, insanlar tarafından oluşturulan yazılı kurallardan oluşan "formel kurumlar" ile gelenek-görenek örf-adet gibi kurallarından oluşan "enformel kurumlar" ayrımı da bulunmaktadır. Bir diğer bir ayrıma göre ise kurumlar; mülkiyet hakları, düzenleyici kurumlar, makroekonomik istikrara yönelik kurumlar, sosyal güvenliğe yönelik kurumlar ve çatışma yönetimine ilişkin kurumlar, şeklinde bir tasnife muhatap olmuşlardır (Acemoğlu ve Robinson, 2001: 74-77; North, 2002: 10; Rodrik, 2000: 4-13).

Esasen çalışmamız bağlamında temel alacağımız tasnife göre ise kurumlar, yönetişim yapısını ve bireysel özgürlük ve siyasi temsil haklarını temsil eden "siyasi kurum"lar, mülkiyet haklarının korunmasının ve sözleşmenin uygulanmasının etkinliğini sağlayan "ekonomik kurum"lar ile hukukun üstünlüğü, yolsuzluğun kontrolü ile yargı ve polis gibi uygulama mekanizmaları da içeren/sağlayan "sosyal kurum"lar şeklinde bir ayrıma konu olabilmektedir. Siyasi kurumlar, resmi bir güce siyasi iktidar tarafindan oluşturulan kurallar ve karar süreçleri ile bireylerin hareketlerini ve davranışlarını tanzim eden kurallar bütününe karşılık gelmektedir. Bu kurumların rolü, bireylerin davranışlarını ve motivasyonlarını belirlemek/değiştirmek, karar alma ve uygunsuz davranışları kısıtlama yetkisine sahip olma bakımından ise toplum içerisinde hiyerarşi yaratarak, bireylerin toplumsal çıkarlardan bağımsız hareket etmelerine mani olmaktır. Siyasi kurumlar, ekonomik kurumlar üzerinde güçlü bir etkiye sahip olup, siyasi iktidarlar ise kaynakların kendi lehine dağıtımını sağlayacak kurumların şekillendirilmesi noktasında bir motivasyona sahiptirler. Bu bağlamda, ülke yönetimlerinin demokrasi, diktatörlük veya otokrasi şeklindeki örgütlenmesi, siyasi iktidarın ekonomik kurumlarla olan ilişkilerinin gücünü ve doğasını önemli ölçüde etkilemekte/farklılaştırmaktadır. Ancak çoğu kez müşahede edilmektedir ki, her ne şekilde örgütlenirse örgütlensin siyasi iktidar, güçlü çıkar gruplarını kontrol etmek istemekte ve bu bağlamda bireyin mülkiyet haklarını kısıtlayıcı/daraltıcı kurallar/mekanizmalar üreterek/tesis ederek, sürdürebilirliklerini temin etmek istemektedirler (Kryeziu ve Coşkun, 2018: 86; Kaufmann, Kraay ve Mastruzzi, 2010: 2).

Kurumların niteliksel özelliklerinin ön plana çıkararak belirli bir metodoloji etrafında parametreleri anlamlı nicel veri setleri haline getiren çeşitli uluslararası ekonomik örgütler, sivil toplum düşünce kuruluşları ve akademik kurumlar bulunmakta olup, Lübnan'da "siyasal 
kurum”ların gelişiminin analize konu edileceği bu çalışmada verilerine başvurulacak olan Dünya Bankası Dünya Yönetişim Göstergeleri, Freedom House Dünya'da Özgürlükler Endeksi ile The Economist Demokrasi Endeksi "siyasal kurum"ları temsilen ampirik ve teorik çalışmalarda sıklıkla referans verilen önemli veri setleri olarak sayılabilir. Esasen ülkelerin siyasal kurumlarını derecelendirmek maksadıyla önemli bir kısmı özel danışmanlık şirketleri ve/veya düşünce merkezleri tarafından oluşturulan bu veri setleri, çoğu kez öznellik, içsellik ve yanlılık sorunları barındırmaktaysa da yapılan regresyon analizlerinde kullanılan çeşitli yöntemlerle bu sorunlar belirli ölçüde kontrol edilebilmektedir (Uğur, 2011: 39).

Çalışmada verilerinden faydalanılan Dünya Yönetişim Göstergelerinde ifade özgürlüğü ve hesap verilebilirlik, siyasal istikrar ve şiddetsizlik, yönetimin etkinliği, hukukun üstünlüğü düzenlemelerin kalitesi, yolsuzluğun kontrolü olmak üzere altı kurum seti bulunmakta, bunlardan seçim, hesap verilebilirlik ve yönetimin değiştirilmesi gibi hususların ölçülmesine ilişkin olarak hesaplanan ifade özgürlüğü ve hesap verme sorumluluğu ile siyasi istikrar ve şiddet yokluğu göstergeleri Siyasal/Politik Göstergeler/Seçme ve İzleme göstergeleri kavramlaştırılabilmektedir. Dünya Yönetişim Göstergeleri ${ }^{2}$, her ülke için -2,5 ile +2,5 arasında puanlanmakta, daha sonra bu altı alana ait puanların ortalaması hesaplanmak suretiyle ilgili ülkenin ortalama skoru tespit edilmektedir.

Diğer bir gösterge olan Freedom House endeksinde, politik haklar ve bireysel özgürlükler olmak üzere iki temel kategori perspektifinden ele alınmakta ve ekonomik özgürlükten ziyade sivil ve politik özgürlükler ele alınmaktadır. Bu çerçevede her iki kategoride de -1- ile -7- arasında bir puanlandırılmaktadır. 1 en yüksek özgürlük derecesini nitelendirirken, 7 ise en düşük özgürlük seviyesini göstermektedir. Bu bağlamda ülkeler, Özgür Ülkeler (F), Kısmen Özgür Ülkeler (PF) veya Özgür Olmayan Ülkeler (NF)şeklinde sınıflandırılmaktadır. ${ }^{3}$

60 göstergeden faydalanılarak hazırlanan ve son olarak 167 ülkenin değerlendirildiği The Economist Demokrasi Endeksine göre ise ülkeler 0-10 puan arasında oylanmakta olup, bu göstergeye göre ülkeler, 0-4 arasında puana sahipse Otoriter Rejim, 4-6 arası puana sahipse Hibrit Rejim, 6-8 arasında bir puanı bulunuyor ise Kusurlu Demokrasi ve nihayet 8-10 puan arası bir puanı var ise Tam Demokrasi olarak tasnif edilmektedir.

\footnotetext{
${ }^{2}$ Detaylı bilgi için bkz. Kaufmann, Kraay \& Mastruzzi, 2010: 1-12

${ }^{3}$ Detaylı bilgi için bkz. https://freedomhouse.org/report/methodology-freedom-world-2018 (Erişim: 24.08.2019)
} 

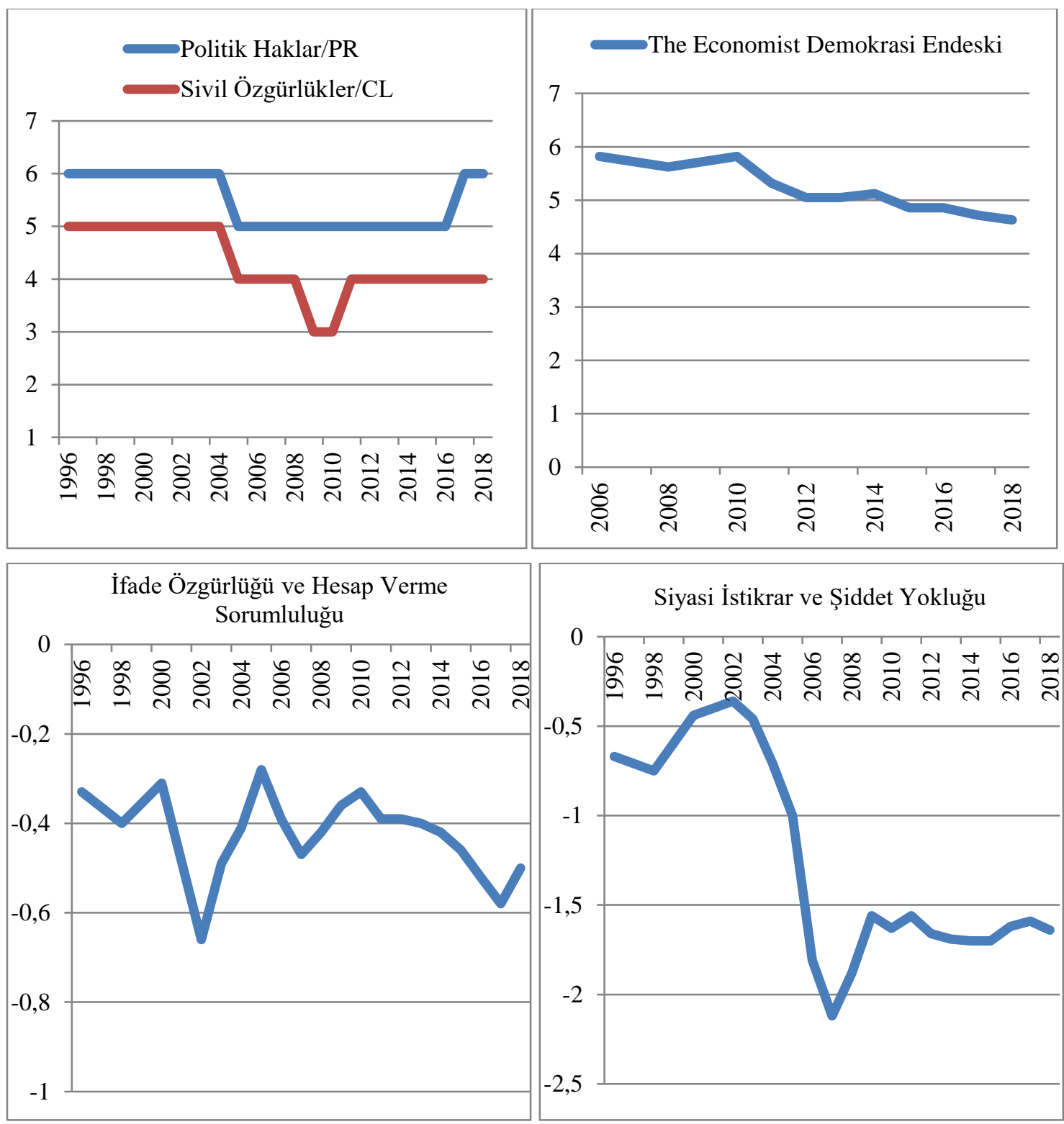

Şekil 1. Lübnan'da Siyasal Kurumların Gelişimi 1996-2018

Kaynak: World Governance Indicators, The Economist Intelligence Unit's Democracy Index ve Freedom House Freedom in the World verileri kullanılarak oluşturulmuştur.

Dünya Yönetişim Göstergelerinin siyasal kurum seti olarak tasnif ettiği Ífade Özgürlüğ̈̈ ve Hesap Verme Sorumluluğu değişkeninde ülkenin analize konu olan1996-2018 yılları arasında oldukça düşük bir performans sergilediği ve 1996 yılı itibariyle $-0,33$ olan skorunun 2018 yılına gelindiğinde $-0,58$ düzeyine gerilediği görülmektedir. Bir ülkenin vatandaşlarının kendi hükümetlerini seçme ve temsil edilme özgürlüğü ile örgütlenme özgürlüğü ve özgür bir medyaya sahip olma gibi temel demokratik değerlerine ilişkin algıları ifade eden bu değişkende var olan düşük performansın yıllar itibariyle arttırılamaması yanında daha da düşük düzeylere gerilemesi hususu ülkenin genel olarak demokratik standartları yakalama anlamında sorunlar yaşadığını ortaya koymaktadır. Kaldı ki, emek, onur ve özgürlük talepleri ekseninde gelişen ve büyük halk kitlelerinin katıldığ $1 /$ destek verdiği protesto gösterilerini ifade eden Arap İsyanlarının bölgeyi etkisine aldığı 2010 yılından sonra bahse konu göstergenin, toplumsal tansiyonun düşürülmesi 
maksadıyla atılacak adımlarla yükselme eğilimine sahip olması beklenirse de tam tersi olacak şekilde skor azalma eğilimini sürdürerek oldukça düşük düzeylere gerilemiş bulunmaktadır.

Diğer siyasal kurum parametresi olan ve yönetimin anayasaya aykırı veya şiddet yöntemleri ile istikrarsızlaştırılması ya da devrilebilmesi olasılığına dair algıları ölçen Siyasi İstikrar ve Şiddet Yokluğu göstergesinde de tıpkı Iffade Özgürlüğü ve Hesap Verme Sorumluluğu değişkeninde olduğu gibi bir azalma trendinin olduğu görülmektedir. Şöyle ki, 1996 y1lı itibariyle -0,67 olan skor, 2018 y1lına gelindiğinde önemli bir düşüş göstererek -1,64 düzeyine gerilemiş bulunmaktadır. Bu noktada, özellikle Temmuz 2006 İsrail'in Lübnan müdahalesi sonrasında yaşanan belirsizlik ve şiddet ortamında, bahse konu gösterge büyük azalış trendine (2007 yılı puanı: -2,12) konu olmuş, ilerleyen yıllarda da halen düşük olmakla birlikte kısmi düzelmeler meydana gelmiş ancak yaşanan iç savaşlar, uluslararası ve bölgesel güç mücadelesi ekseninde yürütülen vekâlet savaşları ve önemli siyasi figürlere yönelen suikastlar gibi şiddet ve istikrarsızlı̆̆ 1 körükleyen etkenler altında düşüş trendini sürdüre gelmiştir. Bu noktada, 2017 yılında gerçekleştirilen seçim sistemine yönelik düzenlemenin ise hâlihazırda ülkenin siyasal istikrarının temini noktasında bir gelişmeye henüz neden ol(a)madığı/sebebiyet veremediği müşahede edilebilmektedir.

Diğer siyasal kurum seti olan Freedom House Politik Haklar ve Sivili Özgürlükler veriler bağlamında Lübnan çalışma döneminde anlamlı bir artış trendi yakalayamamış, ülkede düşük özgürlük skorları kronik bir hal almış gözükmektedir. 1996-2005 döneminde özgür olmayan ülkeler sınıfında tasnif edilen Lübnan, bu yıldan sonra iç savaşlar ve çatışmalar nedeniyle sıkışan ülke atmosferinde yoğunlaşan kısmi özgürlük arayışlarına cevap verecek şekilde gerçekleştirilen siyasi, ekonomik ve sosyal düzenlemeler ile buna yönelik ortaya konulan değişim/dönüşümleri hayata geçirmek suretiyle klsmen özgür ülkeler sinıfinda yer almayı başarabilmiştir. Ancak tüm bu gelişmelere nazaran 2018 yılı verisi itibariyle de ülke, gerek basın özgürlüğü gerekse de toplam özgürlük puanları itibariyle kısmen özgür ülke konumu sürdürmektedir.

Son siyasal kurum seti olan The Economist Demokrasi Endeksi verileri incelendiğinde, etnik, dini ve kültürel toplulukların geniş kapsamlı ve kısmen demokratik bir ortak yönetim modeli çerçevesinde yönetilmekte olan Lübnan'da, demokratik gelişimin ileri düzeyde olmadığı görülmemektedir. Şöyle ki, endeksin başlangıcı yılı olan 2006'da 5,82 puanla Hibrit Rejim olarak tasnif edilmekte olan ülkenin geçen y1llar itibariyle skoru 4,63'e gerilemiş ancak halen Hibrit Rejimler arasında sınıflandırılmaya devam etmiştir. Ülke diğer siyasal kurum setlerinde olduğu gibi bu alanda da bir iyileşme trendi yakalayabilmiş değildir. Hatta özellikle Arap Baharı sonrası süreçte ülkenin skorundaki düşüş trendi, ülkenin otoriter rejimlere yaklaşmasına dahi sebebiyet vermiştir ki son derece kritik ve kırılgan dengeler üzerinden kurgulanmış parçalanmış bir siyasi yapıya sahip olan ülkenin siyasal sisteminde katılımcılı̆̆ın azalma eğilimi gösteren bu durum, potansiyel bir risk de barındırmaktadır.

Marunîler, Dürzîler, Şiiler ve Sünniler başta olmak üzere Keldaniler, Kıptiler, Ermeniler gibi özellikle bağımsızlık sonrası süreçte aralarında birçok çatışmanın yaşandığı çeşitli farklı grup ve mezhebe uzun zamandır ev sahipliği yapmakta olan ve Ahmet Cevdet Paşa tarafindan "Nuh 'un Gemisi" olarak adlandırılan/tanımlanan Lübnan, her ne kadar nev-i şahına münhasır ve kısmi demokratik sayılabilecek "ortaklaşmacı" parlamenter bir cumhuriyet modeli ile yönetilmekte ise de, özellikle ülkenin demografik yapısında olan değişimi yönetime yansıtmak isteyen grupların ortaya çıkardığı çatışmaların toplumun geneline yayılması ve iç savaşlara dönüşmesi gibi hususlar, ülkenin siyasal atmosferinin devamlı olarak gergin bir şekilde devam etmesine sebebiyet vermiştir. İlk dönemlerde Hristiyan ve Müslüman Araplar arasındaki kimlik çatışması, zamanla Şiilerin gücünün artması dolayısıyla diğer Arap Devletleri ile İran'ın çatışmasına da öncülük etmektedir. Yine uzun zamandır uygulanmakta olan çoğunluk esasına dayanan seçim sisteminin doğasından kaynaklı ve tüm bu sınırlı siyasi katılım sorunlarını 
pekiştiren güçsüz merkezi otorite, kırılganlığ 1 son derece yüksek politik sistem, hantal bürokratik ve adli yapı nedeniyle ortaya çıkan düşük hukuk güvenliği ve yaygın yolsuzluk algısı gibi sosyal yönetişim kurumlarına ilişkin problemler gibi hususlar, anayasal haklar ile politik/sivil özgürlükler konusunda günümüze değin bir istikrar sağlanamayan bir ülke modelinin ortaya çıkmasına da neden olmuştur (Yetim, 2018: 35, Taflıŏlu, 2016: 41; Turan, 2011:195; Şöhret, 2012: 93-94).

Her ne kadar bu yöndeki taleplerin karşılanması, toplumsal birlikteliğin sağlanması ve politik istikrarın teminine yönelik olarak nispi temsile ağırlık veren bir seçim sistemi değişikliğe gidilmişse de siyasal, sosyal ve ekonomik ihtilafları çözecek güçlü kurumlarının teşkilatlandırılamamış olması, devam eden makro-ekonomik istikrarsızlıklar, kaynakların verimsiz ve etkin olmayan şekilde kullanımı yanında Lübnan siyasetini belirleme noktasında etkin bir konumda bulunan İran ve diğer Arap Devletleri arasında sürmekte olan ve çoğu kez yıkıcı etkileri bulunan rekabetin geçen süreçte Hizbullah'ın yükselen konumu nedeniyle kısmen de olsa İran lehine değişmesi gibi hususların, ülkede kurumsal değişimin/dönüşümün önündeki en önemli engeller oldukları, anlaşılmıştır.

$\mathrm{Bu}$ bağlamda, siyaset kurumunu ve siyasetçilerin davranışlarını tanzim eden, siyasi sistemi mezhepler aras1 dengeyi korumaktan ziyade mezhepler üstü bir zemine oturtan, sivil siyasetin gelişmesine ve yerleşmesine imkân tanıyan, hesap verebilirliği ve şeffaflığını arttıran sağlam kurumların teşekkül ettirilmesi ile değişen demografik yapı ile uyumlu olacak ve talep eden her bir Lübnan vatandaşının siyasi temsiline imkân sağlayacak siyasal kurumların teşekkül ettirilmesi, ülkenin birliktelik içerisinde sağlam bir geleceğe taşınması açısından son derece önem arz etmektedir.

\section{SONUÇ}

Temsili demokratik sistemlerde seçmenler, kendi adlarına karar alma yetkisini haiz temsilcilerini seçimler vasıtasıyla belirlemekte olup, yasama organı ve hükümetler yapılan bu seçimlerin bir neticesi olarak ortaya çıkmaktadır. Demokratik iktidarın meşruiyet kaynağını ifade etmesi nedeniyle seçimler ve göreve geleceklerin hangi yöntem belirleneceğinin matematiksel alt yapısını oluşturması nedeniyle de seçim sistemleri son derece önemli demokratik araçlar olarak ön plana çıkmaktadır. Hangi siyasi görüşün/partinin kaç temsilci ile parlamentoda olacaklarının belirlenmesinde önemli bir araç olan ve çeşitli teknik ve hesaplama usullerinin kullanılarak oluşturulan seçim sistemlerinin teorik olarak, toplumun tüm kesimlerinin temsiline imkân veren "temsilde adalet" ilkesi ile hükümetin istikrarlı bir şekilde belirlenebildiği ve yönetimi sağladığı "yönetimde istikrar" ilkesini içermesi/karşılaması beklenmektedir. Zira seçim sistemleri, siyasal iktidarların yapılarının belirleyici unsuru olmaktadır Ancak çoğunlukla bu iki ilkenin aynı anda ve aynı ağırlıkta bir arada bulunması imkân ve kabiliyeti bulunmamaktadır. Yönetimde istikrar ilkesine diğer bir ifade ile güçlü siyasi iktidarın varlığına ağırlık verilen ülkelerin çoğunluk sistemlerine, temsilde adalet ilkesine diğer bir ifade ile siyasi iktidarda farklı görüşlerin bulunmasına ağırlık veren ülkelerin ise nispi temsil sistemlerine yöneldikleri müşahede edilmektedir (Aydoğdu, 2015: 41; Akınc1, 2017: 405).

Bir seçim sistemi, farklı toplumsal grupları dışlanması ya da yeterince temsil edilmemelerine sebebiyet veriyor ise bu durum toplumsal tansiyonun yükselmesine ve seçimleri ve sonuçlarını meşru kabul etmeyen grupların ve bunun yerine siyasi hedeflerine ulaşmak için şiddet kullanmalarına sebebiyet verebilmektedir. Diğer yandan, dünya örneklerinden de görülebileceği üzere, çok etnik/dini yapıya sahip olan toplumlarda hem çatışma potansiyelini azaltmak hem de çatışmayı yönetmek ve/veya önlemek için katılımcı seçim sistemleri oldukça etkili bir rol oynayabilmektedir. Bu noktada, parçalı bir görünüm arz eden toplumlarda, "nisbi temsil sistemine" dayalı kapsayıcı bir seçim sisteminin tüm bu kırılganlıkların azaltılması noktasında son derece doğru bir tercih olduğu yönünde çalışmaların bulunduğunu belirtmek 
gerekmektedir. Kültürel, etnik, dini ve mezhepsel farklılıklar içeren, toplumsal çatışma riskinin ve siyasal istikrarsılılı̆ın fazla olduğu bunun yanı sıra iç savaş yaşamış ve bu savaşın siyasal ve toplumsal yapıyı ağır bir şekilde tahrip ettiği çalışma konumuz olan Lübnan'da da, seçim sistemi tercihi ülkede siyasi istikrarının temini ve toplumun tüm kesimlerinin yönetimde etkin ve yeteri oran temsili noktasında son derece önemli bir konu olarak ön plana çıkmaktadır. Esasen kökleri çok eskiye dayanmakta olan ve politik dengelerin mezhep zemininde kurgulandığı nevi şahsına münhasır bir ülke olan Lübnan'da, demokratik temsilin güçlendirilmesi, siyasal aksaklıkların giderilmesi ve siyasi istikrarın temin ve tesisi bakımından 17 Haziran 2017 tarihinde kabul edilen ve katılan her partinin aldığı oy oranında milletvekili çıkarabileceği nispi temsil sisteminin benimsendiği yeni seçim yasasına göre, seçim bölgelerinin 26'dan 15'e düşürülmesi ülkede otoriteyi elinde bulunduran siyasi elitlerin yanı sıra küçük siyasi partilerin de mecliste temsil edilmelerinin yolunun açılması hedeflenmiştir (Akyol ve Mohammed, 2016: 224).

Lübnan'da her ne kadar seçim sisteminde değişikliğe gidilmişse de mevcut seçim sistemlerinin olumlu ve olumsuz sonuçlarının yeterince değerlendirilmeden kurgulandığ 1 gözlenmektedir. Öncelikli olarak, yeni seçim sistemi yürürlüğe girdikten sonra Hizbullah tek başına 13 milletvekiline sahip olarak seçimden en güçlü aktör olarak çıkması ve yalnızca güney Lübnan'da değil Beyrut ve kuzey bölgelerden de önemli oranda oy alması ise partinin sınırlı güce sahip bir kurum olmaktan çıkıp, etkili ve siyasi ağırlığa sahip bir oluşuma dönüşmesi neden olmuştur. Diğer yandan, seçimlerin ardından uzun bir hükümet kurma sürecinin başladığı Lübnan'da güç dengesinin dağılımı da kolay şekilde belirlenememiştir. Bu noktada Hizbullah, istediği bakanlıkları büyük oranda elde ederek parlamentodaki başarısını bakanlıklar düzeyinde de göstermiş olması hususu ise Hizbullah'ın militer gücünün çeşitli vasıtalar (ĕgitim, sağlık ve hayır hizmetleri vs.) ile halk üzerinde oluşturduğu etkinin Lübnan siyasetine ve dolaylı olarakta İran'ın bölge siyasetine etkisi yansıması olarak da kabul edilebilir.

Ancak tüm bu gelişmelere rağmen siyasi temsil politik elitlerin tekelindeki görünümden kurtulabilmiş değildir. Zira 31 Ocak 2019'da hassas dengeler üzerine kurulan Ulusal Birlik Hükümeti'nin bir yılını doldurmadan düșmesi ise 17 Ekim 2019'da başlayan protestoların ülke çapında yayılmasıyla gerek ulusal gerekse de küresel düzlemde geniş yankı bulması ile protestocuların sivil devlet taleplerini dile getirmeleri, Taif anlaşmasına son verilmesi ve siyasi temsiliyetin seküler temeller üzerine oturması yönünde baskıları gibi hususlar, bu tespit ve değerlendirmeleri doğrulayan başlıca hadiseler olarak ön plana çıkmaktadır. Her ne kadar bu gösteriler ertesinde 21 Ocak'ta Hasan Diyab'in başbakanlığında teknokrat bir hükümet kurulmuşsa da siyasi gruplar arasındaki pazarlıklardan doğan güvensiz ortam ve toplumsal grupların kurumsal siyasetin mezhepler arası dengeyi korumaktan ziyade mezhepler üstü bir zemine oturtulması yönündeki talepleri de son bulmuş değildir.

Diğer yandan, ülkede mülkiyet haklarının yeteri ölçüde güvence altına alınamadığı, yolsuzluk ve suiistimalin büyük ölçüde kontrol edilemediği, sözleşmelerin uygulanabilmesine ilişkin mekanizmaların tam ve doğru şekilde oluşturulamadığı, temsilde adaleti sağlayan katılımcı yönetim altyapısının henüz tamamlanamadığı, ekonomik aktörlerin potansiyelini açığa çıkarabildikleri ideal şartları sağlayan kapsayıcı kurumsal yapının teşkil edilmesi suretiyle kurumsal değişimin/dönüşümün de henüz gerçekleştirilemediği de müşahede edilmektedir.

$\mathrm{Bu}$ noktada, öncelikli olarak toplumsal yapının tüm dinamiklerini gözeterek ve dezavantajları da iyice değerlendirerek yeni ve kapsayıcı, sadece siyasi istikrarı değil aynı zamanda toplumsal ve ekonomik istikrarı da hedefleyen bir seçim sisteminin tasarlanmasının, kurumsal dönüşümün/değişimin sağlanabilmesi noktasındaki gerekliliği ortadadır. 


\section{KAYNAKÇA}

Acar, İ. (1989). Lübnan ve Filistin Sorunu, Ankara: Türk Tarih Kurumu

Acemoğlu, D., Johnson, S. \& Robinson J. (2001). The Colonial Origins of Comparative Development: An Empirical Investigation, The American Economic Review. 91(5), 1369-1401

Akboğa, S. ve Şahin, O. (2018). Türkiye'de Demokrasi Algıları: Cinsiyet, Etnik ve Dini Dinamikler, Journal of Economy Culture and Society, 57, 1-28

Akınc1, B. (2017). Cumhurbaşkanlığı Hükümet Sisteminde Seçim Sistemi Arayışları: Dar Bölge Seçim Sisteminin Yönetimde İstikrar Ve Temsilde Adalet Kriterleri Açısından Değerlendirilmesi, International Journal of Social Science, 63, 403-420

Akyıldız, A. (2016). Demokrasinin Sayılarla Sınavı: Seçim Sistemleri, Uyuşmazlık Mahkemesi Dergisi 7, 127-148

Akyol, E. ve Mohammed, Y.Y. (2016), Bölünmüş Toplumlarda Çoğunluk Esasına Dayanan Seçim Sisteminin Zorlukları Ve Azınlıkların Temsili: Etiyopya Örneği, Fırat Üniversitesi Sosyal Bilimler Dergisi, 26(2), 219-236.

Aydoğdu, Y. (2015). Seçim Sisteminin Siyasal Sonuçları, Uyuşmazlık Mahkemesi Dergisi, (6), 41-62

Blais, A. \& Massicotte, L. (1996). Electoral Systems, Comparing Democrasies 2, 40-69

Bulut, N. (2010). Temsilde Adalet-Yönetimde İstikrar İkilemi Bağlamında 12 Haziran 2011 Seçimleri, Erzincan Üniversitesi Hukuk Fakültesi Dergisi, 14 (3-4), 1-18

Counter Extermism Project. (2018) [Çevrim-içi:

https://www.counterextremism.com/sites/default/files/Hezbollah\%20Influence\%20in\%20Lebanon_043018.pdf]

Erişim Tarihi: 08.01.2020

Cumhurbaşkanlığı Osmanlı Arşivi, BEO, GG 1013

Çetin, T. (2012). Yeni Kurumsal İktisat, Sosyoloji Konferanslarl, 45(1), 43-73.

Dani R. (2014). Kaliteli Büyümeye Yönelik Kurumlar: Nelerdir ve Nasıl Kazanılır, Kalkınmada Yeni Yaklaşımlar, Devrim Dumludağ, Ahmet Faruk Aysan (Der), Ankara: İmge Kitabevi Yayınları, 40-45

Demir, Ö. (1996). Kurumcu İktisat, Ankara: Vadi Yayınları.

Diss M \& Steffen F. (2017). The Distribution of Power in the Lebanese Parliament Revisited, halshs-01587503

El Vaili A.H.N \& Naci A. (2014). El Hayatu'n Niyabiyye el Lübnaniyye (1943-1958), Irak: Mecelletü'l Camiati'l Kerbela El İlmiyye

Freedom House, Freedom in the World 2018, Table of Country Scores, [Çevrim-içi: https://freedomhouse.org/reporttypes/freedom-world] Erişim Tarihi: 04.01.2020

Gallager, M. (1991). Proportionality, Disproportionality and Electoral Systems, Electoral Studies, 10(1), 33-51.

Ganley, C.E. (2012). Palestinian Power in Lebanon: The Development of Palestinian Militancy and its Role in the Outbreak of the Lebanese Civil War, Senior Theses, Trinity College, Hartford, CT

Kaufmann, D, Kraay A \& Mastruzzi M. (2010) The Worldwide Governance Indicators-Methodology and Analytical Issues, The World Bank Policy Research, Working Paper. No: 5430

Köprülü N ve Ebrem İ.S. (2013). Lübnan'da Çoklu Güç Paylaşımı ve Ortaklıkçı Demokrasi Zemininin Arap Ayaklanmaları Sonrası Geleceği, Akademik Orta Doğu, 8(1), 1-24

Krayem H. (ty). Political Parties and Electoral Systems in Lebanon and Israel: Interactive Reinforcement, [Çevrim-içi: http://almashriq.hiof.no/ddc/projects/pspa/krayem/krayem.html] Erişim Tarihi: 08.02.2020.

Kryeziu, L. ve Coşkun, R. (2018). Political and Economic Institutions and Economic Performance: Evidence from Kosovo, South East European Journal of Economics and Business, 13(2), 84-99

Laga, A.M, (1991). El-Itticahatü's-siyasiyye fí Lübnan (1920-1982), Beyrut: Müessesetü'r-Risâle

Majed, Z. (ty). Consensus democracy and representation in Lebanon, Between agony and electoral reform [Çevrim içi:https://rc-services-assets.s3.eu-west-1.amazonaws.com/s3fs-public/Accord24_ConsensusDemocracy.pdf] Erişim Tarihi: 21.01 .2020$.

Moussa, N, (2018). The Lebanese Legislative Elections: Fragmentation and Polarization, [Çevrim-içi: https://www.arab-reform.net/wp-content/uploads/pdf/Arab_Reform_Initiative_en_the-lebanese-legislative-electionsfragmentation-and-polarization_2950.pdf?ver=3e4070ffe1e45fb79e843e1acd807c43] Erişim Tarihi: 05.01.2020. 
Nohlen, D. (1996) Seçim Sistemleri, Türkiye ve Avrupa'da Seçim Sistemleri - Uluslararası Konferans Tebliğler Kitabi, Friedrich Ebert Vakfi, İstanbul, 9-54.

Norris, P. (1997). Choosing electoral systems: proportional, majoritarian and mixed systems. International political science review, 18(3), 297-312.

North, Douglass C. (2002) Kurumlar, Kurumsal Değişim ve Ekonomik Performans. İstanbul: Sabanc1 Üniversitesi Yayını

Orhan, S. (2011).Yerleşik İktisatta Ortodoksi: Yeni Kurumsal İktisat,. İktisatta Yeni Yaklaşımlar, Ercan Eren ve Metin Sarfati (Der), İstanbul: İletişim Yayınları, 1. Bask1, 59-87.

Özbudun, E. (1995). Seçim Sistemleri ve Türkiye, Ankara Üniversitesi Hukuk Fakültesi Dergisi, 44 (1), 521-539

Ra'd, M. (ty). Lübnan Min al İmarah ila al Mutasarrıfiyyah: 1840-1861, Beyrut: Dâru Nazir Abbud

Rodrik, D. (2000) Institutions for High-Quality Growth: What They are and How to Acquire Them, National Bureau Economic Research, Working Paper No: 7540, 1-48.

Şöhret, M. (2012). Ulus Devletsiz Devlet Sistemi: Lübnan Modeli, Hitit Üniversitesi Sosyal Bilimler Dergisi, 5(1)I 85-107

Taflığlu, M.S. (2016). Lübnan Anayasal Düzeninde Egemenlik Dağılımı, Sosyoekonomi, 24(28), 31-42

The Economist Intelligence Unit, Democracy Index, [Çevrim-

içi:https://infographics.economist.com/2019/DemocracyIndex/] Erişim Tarihi: 04.01.2020

Tuncer, E. (2014). Çok Partili Dönemde Seçimler ve Seçim Sistemleri, TESAV.

Turan, N.S. (2011). Lübnan'da Ulusun İnşası ve Ortak Tınının Üretimi - Rahbani Kardeşler ve Feyruz”, Ortadoğu Etütleri, 3(1) 193-228

Türk, S. (2006). Seçim, Seçim Sistemleri ve Anayasal Tercih, Anayasa Yargısı, 23, 75-112

Uğur, Mehmet. (2011) Kurumsal Kalite ve Ekonomik Performans: İktisadın (Yeniden) Siyasallaşması Mı?, Iktisat ve Toplum, 1(9), 36-41.

World Governance Indicators, [Çevrim-içi: https://info.worldbank.org/governance/wgi/] Erişim Tarihi: 01.02.2020.

Yetim, M. (2015). Şiddet Eğilimli ve Direniş Temelli Şii Aktivizmi: Hizbullah'ın Fikirsel ve Örgütsel Zemini, Türkiye Ortadoğu Çalşmaları Dergisi, 2(2), 59-88.

Yetim, M. (2018). Iran-Hizbullah İlişkileri (1980-1995): Ulus-Aşırılaşan Şiddet, Akademik Araştırmalar ve Çalışmalar Dergisi, 10(18), 29-42.

Yıldız, A. (2018). Seçim Sistemleri ve Türkiye'de Milletvekili Seçim Sistemine İlişkin Bir Öneri, Selçuk Üniversitesi Hukuk Fakültesi Dergisi, 26(3), 113-153.

Yüzbaşığlu, N. (1996). Türkiye'de Uygulanan Seçim Sistemleri ve Bunlara İliş̧in Anayasa Mahkemesi Kararlarına Göre Nasıl Bir Seçim Sistemi, İstanbul Üniversitesi Hukuk Fakültesi Mecmuası, 55.1-2, 103-150

Zübyan, S. (1977). El-Hareketü'l-Vataniyyetü'l-Lübnaniyye, Beyrut, Dârü'l-Mesire 


\section{Extended Summary}

\section{Restructuring of Political Institutions in Lebanon: From Majoritarian to Proportional Representation}

The aim of this study is to examine the election system change in Lebanon that foresees the transition from the majority system to the relative representation in order to ensure social cohesion and political stability. In this context, the effects of the different political weights and representation status of various social groups in the country's politics on the overall political stability of the country are analyzed within the framework of the New Institutional Economics.

Lebanon is currently governed by a political system in which ethnic, religious and cultural communities are organized within the framework of a comprehensive and partly democratic model of joint government ("collective" parliamentary republic). Accordingly, the President of the Republic is determined from the Christians, the Prime Minister from the Sunnis, and the President of the Assembly from the Shiites. Other minorities have a say in the administration by taking various state duties at different levels. This system and the state structure were shaped according to the first and only census in 1934 and are highly related to religious and sectarian demography.

In this system, which has been in force for a long time in Lebanon, the majority system was implemented, which allowed the political party that received the most votes in an election to have the full representation in that area. However, after the Palestinians' increasing activities in Lebanon, the population balance changed in favor of the Sunnis, the civil war started, the emergence of the Hezbollah Organization as a result of the intense contacts with the Lebanese Shiites within the framework of Iran's "Revolution Issue" policy, and the Shiites lived intensely in South Lebanon and Bekaa. After this, the management structure based on extremely critical balances has already begun to be questioned. Accordingly, issues such as justice in representation have been brought to the agenda with the election system.

From the independence to the present day, Iran's gaining power on Lebanese politics through Hezbollah, the decreasing effect of this country in Lebanese politics due to the great civil war in Syria after the Arab Revolts has become unresponsive. In the Lebanese politics, while the demands of the social groups/actors to increase in the political system have increased, on the other hand, it has been observed that the current management structure is not capable of responding to these demands. This election system has turned into a state that increases the instability in management with this state, which creates problems rather than solutions.

In terms of eliminating all these problems and ensuring political stability, the country has been divided into 15 electoral regions with the new election law, which was adopted as a result of major debates. In this way, the system of relative representation, in which every party participating in the elections could get deputies, was adopted. However, important legal changes in this process kept the agenda of the country quite busy. After this process, the system of relative representation was introduced, but this brought the country to the brink of a new political crisis.

In the first parliamentary elections held after the adoption of the new system, the alliance front, which includes Hezbollah, which is the hostile of important domestic and foreign actors, and which various countries define as a terrorist organization, has achieved a third of the parliament. Thus, an important process started in both Lebanon and the region. Moreover, the government that was established following these elections was not long lasting, and after the protests started in the country, a new government was established under the Prime Ministry of Hassan Diyab supported by Hezbollah and Shia groups. 
In Lebanon, which hosted various actors such as Marunis, Druze, Shiites and Sunnis, such as Keldanis, Copti, and Armenians, a radical reform was made in the electoral system but it was not possible to provide the institutional structure to support this. Again, due to the competition between Iran and other Arab States, which have a decisive influence on Lebanese politics, and the rise of Hezbollah, the change of balance in favor of Iran is the biggest obstacle to social and economic transformation.

Designing an inclusive electoral system that saves the political system from sectarian/ethnic basis politics, enables the development of civil policy, increases accountability and transparency and is compatible with the demographic structure, is crucial for ensuring unity in the country. 